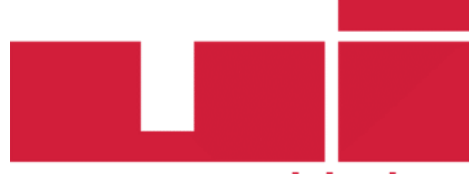

\title{
Türkiye-ABD İlişkilerinde Twitter Diplomasisi
}

\author{
Twitter Diplomacy in Turkey-US Relations
}

\section{Ali Şevket OVALI}

Doç. Dr., Dokuz Eylül Üniversitesi, Uluslararası İlişkiler Bölümü

\section{Bu makaleye atıf için}

Ali Şevket Ovalı, "Türkiye-ABD İlişkilerinde Twitter Diplomasisi”, Uluslararası Ilişkiler, Cilt 17, Say1 65, 2020, s. 23-45, DOI: $10.33458 /$ uidergisi.672450

Makaleye Erişim İçin: https://dx.doi.org/10.33458/uidergisi.672450

Makale Gönderim: 20 Eylü1 2019

Son Düzeltme: 2 Ocak 2020

İnternet Yayım: 20 Ocak 2020

Basım Tarihi: 01 Mart 2020

\section{Uluslararası İlişkiler Konseyi Derneği | Uluslararası İlişkiler}

E-Posta: bilgi@uidergisi.com.tr

Bu makalenin tüm hakları Uluslararası İişkiler Konseyi Derneği’ne aittir. Önceden yazılı izin almadan hiçbir iletişim, kopyalama ya da yayın sistemi kullanılarak yeniden yayımlanamaz, çoğaltılamaz, dağıtılamaz, satılamaz veya herhangi bir ssekilde kamunun ücretli/ücretsiz kullanımına sunulamaz. Akademik amaçlı alıntılar bu kuralın dışındadır. Yazıda belirtilen fikirler yalnızca yazarına/yazarlarına aittir. UİK Derneğini, editörleri ve diğer yazarları bağlamaz. 


\title{
Türkiye-ABD İlişkilerinde Twitter Diplomasisi
}

\author{
Ali Şevket OVALI \\ Doç. Dr., Dokuz Eylül Üniversitesi, \\ İşletme Fakültesi, Uluslararası İlişkiler Bölümü. Tınaztepe Yerleşkesi, Buca, İzmir. \\ E-posta: sevket.ovali@deu.edu.tr
}

\begin{abstract}
ÖZET
Twitter kullanımı son yıllarda dış politika icrasının önemli bir parçası haline gelmiştir. Dış politika yapıcıları dijital diplomasinin yaygın kullanılan biçimlerinden biri olan Twitter’’, gücü ve popülerliğinden dolayı giderek daha fazla kullanmakta ve böylece hem takipçilerini belli başlı konular, problemler veya ülkelerinin dış politika gündemlerindeki güncel başlıklar hakkında bilgilendirip hem de muhataplarına mesajlar göndermektedirler. $\mathrm{Bu}$ çalışma, Twitter'ın dış politika icrasındaki popülerliğinden hareketle, Twitter diplomasisinin Türkiye-ABD ilişkilerindeki rolünü tartışmayı amaçlamaktadır. Çalışma bu amaç doğrultusunda, Amerikalı ve Türk dış politika yapıcılarının Twitter'ı nasıl ve hangi amaçlarla kullandıkları, her iki tarafta seçilen üst-düzey karar alıcıların attıkları tweetlerle ilişkilerdeki hangi başlıklara değindikleri, Twitter' in ikili ilişkilerin mevcut durumu üzerindeki olumlu ve olumsuz etkileri ile ilişkilerin geleceğinde oynayabileceği rolleri analiz etmektedir.
\end{abstract}

Anahtar Kelimeler: Dijital Diplomasi, Twitter Diplomasisi, Türk Dış Politikası, Türk-Amerikan İlişkileri, Trump

\section{Twitter Diplomacy in Turkey-US Relations}

\begin{abstract}
The use of Twitter has become an important part of foreign policy making and conducting in the recent years. Since it is seen as the most powerful and popular tool of digital diplomacy, foreign policy makers increasingly use Twitter for sending messages to their counterparts and to inform their followers on certain issues, problems or current topics on their country's foreign policy agenda. Taking the popularity of Twitter use in foreign policy, this study aims to discuss the role of Twitter diplomacy on Turkey-US relations. In this respect, how and for which purposes foreign policy makers in Turkey and the US use Twitter, which topics are mostly covered by the tweets of the selected toplevel decision-makers' accounts, the positive and negative impacts of Twitter on the current status of bilateral relations and the role that Twitter is likely to play in the future of relations are the points that are going to be dealt within the framework of this study.
\end{abstract}

Keywords: Digital diplomacy, Twitter Diplomacy, Turkish Foreign Policy, Turkey-US Relations, Trump. 


\section{Giriş}

21 Mart 2006 'da Jack Dorsey tarafından atılan ilk mesajla sanal dünyaya giriş yapan mikroblog sitesi Twitter, bugün 14. yılını kutlarken basit bir iletişim platformu olmanın ötesinde fonksiyonlara sahip olduğunu hem kendi kullanıcılarına hem de internet temelli çalışmalar yürüten araştırmacılara göstermiştir. Twitter’ın özellikle 2000'li yıllarda dış politika ve uluslararası ilişkiler alanlarındaki karar alıcılar tarafından artan biçimde kullanılması, Twitter diplomasisi kavramını 21. Yüzyıl dijital diplomasisinin önemli bileşeni haline getirmiştir. ${ }^{1}$ Konu üzerine şimdiye kadar yapılan en kapsamlı çalışmayı yürütmekte olan New York merkezli küresel iletişim ajansı Burson, Cohn and Wolfe (BCW) tarafından Twiplomasi olarak isimlendirilen Twitter diplomasisi, bugün pek çok devlet başkanı, bakan veya ilgili devleti temsille yetkili kişilerin kullanmakta oldukları klasik diplomasiyi tamamlayan bir dış politika icra aracı haline gelmiştir.

Özelde Twitter'ın genelde ise sosyal medya platformlarının bir diplomatik faaliyet aracına dönüşmesi klasik diplomaside dört önemli ve zorunlu değişime yol açmıştır. Birincisi, ülkeyi temsille yetkili liderlerin bu platformlar sayesinde muhataplarına ve kamuoylarına mesaj iletmek için eskiden kullandıkları klasik yöntemlere bağımlılıkları azalmıştır. Buradan tabii ki liderlerin Twitter aracılı̆̆ı ile diplomatları veya dışş̧leri teşkilatlarını tamamen devre dışı bıraktıkları, klasik diplomasiyi ve yöntemlerini bir kenara ittikleri ve dış politikayı anlık Twitter mesajlarıyla yönettikleri sonucu çıkartılmamalıdır. Fakat şu da bir gerçektir ki, liderler dış politikaya dair anlık mesajlarını ve görüşlerini iletmek için özel kuryelere, şifreli telgraflara, özel görevlendirilmiş temsilcilere ve teferruatlı basın toplantılarına eskiye nazaran daha az ihtiyaç duymaktadırlar.

İkinci değişim ise, Twitter gibi platformlar aracılığı ile klasik diplomasideki zaman-mekân kavramlarının ortadan kalkmasıdır. Dışişleri teşkilatlarında, deneyimli diplomatlar tarafından üzerinde saatler, hatta günler harcanarak titizlikle hazırlanan mesajlar ve o mesajların iletildiği mekanların sembolizmi, Twitter gibi sosyal medya platformlarında anlamsız hale gelmiş, "gönder" butonu ile aynı anda yüzbinlerce kullanıcıya ulaşan mesajlar klasik diplomasideki zaman-mekân ve kavramlarını sanal dünyada ortadan kaldırmıştır. 1812 yılındaki İngiliz-Amerikan Savaşı’nı bitiren Gent Anlaşması'nın sahadakilere ancak bir ay sonra ulaştığı ve bu süre içinde tarafların savaşmaya devam ettikleri ${ }^{2}$ dikkate alınırsa, iletişim devrimi ve dijitalleşmenin klasik diplomasinin zaman-mekân alışkanlıkları ve pratikleri üzerindeki etkileri daha iyi anlaşılacaktır.

Üçüncü önemli değişim, klasik diplomasinin sadece diplomatları ve politikacıları oyuna katan ve sivilleri dışarıda bırakan dışlayıcı (exclusive) doğasında görülmüştür. Bir başka deyişle asırlardır klasik diplomasinin en önemli prensibi olan gizlilik, internet ve sosyal medya kullanımıyla birlikte yıkılmaya başlamıştır. ${ }^{3}$ Twitter ve diğer sosyal medya platformları sayesinde tüm internet kullanıcıları

12013 yllında 193 Birleşmiş Milletler (BM) üyesi ülkenin kabaca \%78'i Twitter'da resmi olarak temsil edilirken 2018 yılında bu oran \%97’e çıkmıştır. Chu Wang, “Twitter Diplomacy: Preventing Twitter Wars from Escalating into Real Wars", Harvard Kennedy School Belfer Center for Science and International Affairs, Future Diplomacy Project, 20 May1s 2019, https://www.belfercenter.org/publication/twitter-diplomacy-preventing-twitter-wars-escalating-real-wars , (Erişim Tarihi 13 Aralık 2019)

2 Philip Seib, The Future of Diplomacy, Cambridge, Polity Press, 2016, s. 19.

3 Alexis Wichowski, "Secrecy is for Losers: Why Diplomats Should Embrace Openness to Protect National Security", Corneliu Bjola ve Marcus Holmes (der.), Digital Diplomacy: Theory and Practice, Londra, Routledge, 2015, s.53. Benzer düşünceleri paylaşan Gilboa, geleneksel diplomasinin ayırtedici özelliklerini "kişisel, resmi, zaman alan ve gizli” olarak tanımlamaktadır. Eytan Gilboa, "Real-time diplomacy: Myth and Reality”, Evan H. Potter (der.), Cyber Diplomacy: Managing Foreign Policy in the Twenty-First Century, Montreal, McGill-Queen's University Press, 2002, s.84. 
diplomasinin bir parçası haline gelmişler ve diplomasi farklı aktörleri de işin içine katan (inclusive) kapsayıcı bir kimliğe bürünmüştür. İletilen mesajlar ve alınan etkileşimler gazeteciler, sivil toplum örgütü temsilcileri, farklı gruplar ve bireyler tarafından okunur hale gelmiş ve enformasyon bu sayede hızla yayılmaya başlamıştır. Bu etki hiç şüphe yok ki gizliliğin temel prensip olduğu klasik diplomasiyi daha açık ve şeffaf hale gelmeye zorlamaktadır.

Dördüncü değişim politikacıların ve bürokratların kişisel (personal), çoğu zaman yüz yüze ilişki kurma biçimlerinin yanına, giderek kişisel olmayan (impersonal) ve Internet üzerinden kurulan ilişki biçimlerinin eklenmeye başlamasıdır. Bu durum klasik diplomaside büyük öneme sahip ses tonu, jest, mimik, vücut dili kullanımı ve iletişim becerileri gibi unsurların yerlerini sanal ortamda onaylama, beğenme, paylaşma, etiketleme veya gönderiye yorum yapma gibi gerçek ama bir o kadar da sanal reaksiyonların almasıyla sonuçlanmıştır. Yüz yüze veya kişisel olmayan sanal temasların devlet insanlarını yüz yüzeyken yapamayacakları ve diplomatik teamüllere aykırı davranışlara cesaretlendirdiği ve krizlere sebebiyet verdiği de görülmektedir. Örneğin Brezilya Devlet Başkanı Jair Bolsonaro'nun Facebook üzerinden yaptığı bir yorumla Fransa Cumhurbaşkanı́nı Emmanuel Macron'un eşi Brigitte Macron'un yaşıyla alay etmesi ve doğrudan Macron'dan aldığı sert tepki bu krizlerin ne ilki ne de sonuncusu olacaktır. ${ }^{4}$

Klasik diplomasinin maruz kaldığı sosyal medya veya Twitter etkisi, devletler arası iletişim ve etkileşimi daha şeffaf ve kolay kılıyor hatta kuvvetlendiriyor gibi gözükse de pek sıklıkla karşılıklı yanlış anlaşılmalara, krizlere ve gerilimlere de neden olmaktadır. Twitter, klasik diplomasinin tersine ikili veya çoklu iletişimden ziyade dış politika yapıcıları tarafından genellikle tek taraflı bir mesaj iletimi için kullanıldığından kriz yaratma potansiyeli yüksek bir araca da dönüşebilmektedir. Üzerinde düşünülmeden veya sonucu yeterince hesaplanmadan atılan anlık mesajlar hem diplomatları sürekli kriz durumlarına hazır bulunmaya zorlamakta hem de klasik diplomaside pek karşılaşılmayan ve telafisi zor sorunlar doğurabilmektedir. Ancak yine de devletler, tüm bu olumsuzluklara rağmen dijital çağın gerektirdiği diplomatik dönüşümlere uyum sağlamaya çalışmakta ve klasik dışişleri teşkilatlarında internet ve sosyal medya ile ilişkili birimlerin operasyonel kabiliyetlerini geliştirmeye devam edilmektedir. ${ }^{5}$

Son dönem Türk-Amerikan ilişkileri de Twitter'ın kriz üreten etkilerine maruz kalmıştır. Twitter'ı aktif olarak kullanan liderlerin başında gelen ABD'nin 45. Başkanı Donald Trump, göreve

4 “Macron eşinin yaşıyla alay eden Bolsonaro’ya 'saygısız' dedi”, BBC News Türkçe, 26 Ağustos 2019, https://www.bbc. com/turkce/haberler-turkiye-49477314 (Erişim Tarihi 29 Ağustos 2019).

5 ABD Dışişleri Bakanlığı’nda 2002'de birkaç çalışanla kurulan ve ilk zamanlarında E-diplomasi Görev Gücü adıyla bilinen ofis, Condeleezza Rice ve Hilary Clinton dönemlerinde gelişmiş ve Amerikan dış politikasının önemli enstrümanlarından biri haline gelmiştir. Bugün ABD’nin yurtdışındaki 900 civarı diplomatik temsilcisine hizmet veren birim, aynı zamanda dışişleri merkez teşkilatında da 25 alt birimle faaliyet göstermektedir. ABD'nin e-diplomasi konusunda bakanlık düzeyindeki girişimleri hakkında ayrıntılı bir rapor için bkz. Fergus Hanson, Revolution @State: The Spread of e-Diplomacy, Lowy Institute for International Policy, Sydney, March 2012. Ayrica bkz. Corneliu Bjola, Markus Kornprobst, Understanding International Diplomacy: Theory, Practice and Ethics, Newyork, Routledge, 2013, s. 161. Sosyal medya platformlarını diplomatik araç olarak kullanma eğilimi İngiltere Dışişleri Bakanlığı bünyesinde de giderek artan biçimde desteklenmektedir. Deneyimli İngiliz diplomat Hugh Elliott, bugün dünya çapındaki İngiliz büyükelçilikleri, konsoloslukları ve misyonlarının 7 milyonun üzerinde takipçi tarafından izlenen 700'den fazla resmi sosyal medya hesabına sahip olduklarını ifade etmektedir. Büyükelçi Elliott, İngiltere Dışişleri Bakanlığı́nın kendisini değişen dünyaya en hızlı adapte eden bakanlık olduğunu iddia ederken, bakanlığın Snapchat hesabına sahip ilk Dışişleri Bakanlığı olması da bu iddiayı destekler niteliktedir. Hugh Elliott, "Digital Diplomacy: Are We the Champions?” Foreign and Commonwealth Office Blog, 30 Mart 2017, https://blogs.fco.gov.uk/guestpost/2017/03/30/digital-diplomacy-arewe-the-champions/ (Erişim Tarihi 29 Ağustos 2019). 
geldiğinden bu yana dış politikaya dair kimi görüşlerini Twitter üzerinden paylaşırken, attığı tweetlerin Türkiye ile ilgili olanları iki ülke arasında yaşanan krizleri daha görünür hale getirmiştir. Amerikan dışişleri bakanı ve ulusal güvenlik danışmanının Twitter hesaplarından da zaman zaman Türkiye ile ilgili tweetler atılmış, Türkiye'den yetkili isimlerin attıkları tweetler veya basın aracılığı ile verdikleri cevaplar ile de krizler kamuoyunun gözü önünde cereyan eden hadiselere dönüşmüştür.

Bu çalışma Twitter'ın Türk-Amerikan ilişkilerinde nasıl bir rol oynadığını, Donald Trump'ın Başkan seçildiği 8 Kasım 2016'dan 22 Ekim 2019’a kadar uzanan bir zaman dilimine odaklanarak tartışmayı amaçlamaktadır. Bu tartı̧̧ma ekseninde cevap aranacak üç temel araştırma sorusu şunlardır: Araştırma için seçilen siyasi aktörler Twitter'ı ikili ilişkiler bağlamında nasıl ve hangi gündem başlıklarında kullanmaktadırlar? Bu aktörler Twitter'ı Türk-Amerikan ilişkileri bağlamında hangi amaçlarla kullanmaktadırlar? Twitter'ın Türk-Amerikan ilişkilerindeki rolü nedir, gelecekte ne olacaktır? Çalışmada bu temel araştırma sorularının yanı sıra dijital diplomasi ve Twitter diplomasisi nedir, sosyal medyanın klasik diplomasi üzerindeki etkileri nelerdir, dışişleri teşkilatlarını sosyal medya çağında ne gibi zorluklar beklemektedir gibi alt araştırma sorularına da cevaplar aranacaktır. Çalışma, bu sorulara verilecek cevaplarla Twitter diplomasisi hakkında Türkçe yazın oluşumuna, kavramsal bir çerçeve çizerek ve bu çerçeveyi vaka analizi yoluyla destekleyerek katkı sağlamayı hedeflemektedir. Çalışmanın ilk bölümünde kavramsal çerçeve çizilecek; ikinci bölümde yöntem, üçüncü bölümde bulgular ortaya konacaktır. Son bölümde ise elde edilen bulgular temelinde Twitter'ın Türk-Amerikan ilişkilerinin güncel ve gelecekteki rolü üzerine değerlendirmeler yapılacaktır.

\section{Kavramsal Çerçeve}

Uluslararası İlişkiler ve dış politika yazınındaki pek çok sözlük ve temel kavram kitapları diplomasiyi klasik ve dar bir perspektiften tanımlamaktadırlar. Bu çerçevedeki diplomasi tanımları "devletlerin iletişim haline bulunmaları", "devletlerin dış politikalarını uygulamaya koymaları", "egemen devletlerin kendi ülkelerinde veya yurtdışında bulunan resmi görevlileri aracılığı ile ilişkilerini yürütmeleri”, "devletler sisteminin parçası olan devletlerin resmi kanallar yoluyla iletişim halinde bulunmaları" gibi klasik tanımlardır. Hedley Bull'un sıkça atıfta bulunulan kavramsallaştırması diplomasiyi, "devletler ve dünya politikasındaki diğer yapıların, ilişkilerini resmi görevliler aracıllğı ile ve barışçl yollarla yürütmesi”"10 olarak tanımlarken, Watson’a göre diplomasi "birbirlerinin bağımsızlıklarını kabul eden politik birimlerin müzakerelerine verilen addır". ${ }^{11}$ Plano ve Olton'un ilk baskısı 1968'de yapılan Uluslararası İlişkiler Sözlüğünde ise, diplomasinin "hem dış politikanın planlanmasını hem de bu politikanın icrasını kapsadığı, bu yüzden de diplomasi ve dış politikanın aynı şeyler olduğu" ${ }^{\prime 2}$ ifade edilmektedir.

6 Peter Lamb, Fiona Robertson-Snape, Historical Dictionary of International Relations, Londra, Rowman \& Littlefield, 2017, p.96.

7 Martin Griffiths, Terry O'Callaghan, International Relations, The Key Concepts, Londra, Routledge, 2002, p.79.

8 G.R. Berridge, Lorna Lloyd, The Palgrave Macmillan Dictionary of Diplomacy, Third Edition, Hampshire, Palgrave Macmillan, 2012, s.97-98.

9 G.R. Berridge, Maurice Keens-Soper and T.G.Otte, Diplomatic Theory From Machiavelli to Kissinger, Hampshire, Palgrave Macmillan, 2001, s.1.

10 Hedley Bull, The Anarchical Society, A Study of Order in World Politics, Third Edition, Hampshire, Palgrave, 2002, p. 156.

11 Adam Watson, Diplomacy, The Dialogue Between States, Taylor Francis E-Library Version, 2005, p. 21.

12 Jack C. Plano, Roy Olton, The International Relations Dictionary, Fourth Edition, Santa Barbara, ABC-Clio, 1988, p.241. 
Klasik tanımların biraz dışına çıkarak diplomasiyi “toplumsal bir soruna cevaben ortaya çıkmış bir kurum" olarak tanımlayan Jönsson ve Hall, bu sorunu "politik toplulukların hem birbirilerinden ayrı yaşamak hem de birbirleriyle ilişki kurmak istemeleri” olarak ortaya koymaktadırlar. ${ }^{13}$ Kavramın politik topluluklar arasındaki ilişkinin normlarını ve değerlerini barındıran ve bu norm ve değerler ekseninde kişilere roller yükleyen bir kurum olarak görülmesi gerektiğini belirten Jönsson ve Hall’a göre, diplomasinin yüzyıllardır varlığını sürdürmesi ancak bir kurum olarak var olması ile açıklanabilir. ${ }^{14}$

Uluslararası ilişkilerin Soğuk Savaş'ın bitişinden bu yana geçirdiği dönüşüm dikkate alındığında, ister dar isterse geniş anlamda olsun, klasik diplomasi kavramsallaştırmalarının bugünün dinamiklerini anlamakta yetersiz kaldığı görülmektedir. Benzer bir iddiada bulunan Constantinou, Kerr ve Sharp, diplomasi kavramının geçirdiği evrimin ve bugün kapsadığı alanın ortaya ciddi bir ikilem çıkardığını savunmaktadırlar. Öyle ki, diplomasi klasik ve dar anlamda egemen devletlerin akredite olmuş temsilcileri aracılığı ile yürüttükleri ilişkiler olarak tanımlanırsa bugün diplomasi başlığı altında yürütülen pek çok faaliyetin bu kategoriye girmediği görülecek; geniş bir anlamda uluslararası politika alanındaki tüm ilişki biçim ve metotları olarak tanımlanırsa da diplomasi ve diplomat kavramları giderek daha bulanık ve muğlak kavramlara dönüşecektir. ${ }^{15}$ Bugün sıkça karşımıza çıkmaya başlayan yerel diplomasi, dijital diplomasi, ${ }^{16}$ diaspora diplomasisi, spor diplomasisi, Twitter diplomasisi ve hatta ünlü diplomasisi ${ }^{17}$ gibi kavramlara ve içeriklerine bakıldığında klasik diplomasinin günümüz dinamikleri karşısında nasıl bir değişim ve dönüşüm baskısına maruz kaldığı kolayca görülecektir. Bir başka deyişle, uluslararası ilişkiler 19. yüzyılın başlarındaki biçiminden günümüze nasıl evrim geçirip başkalaştıysa, bu ilişkilerin yürütülme biçimleri de büyük değişimler geçirmiştir. ${ }^{18} \mathrm{Bu}$ değişimler diplomasinin farklı boyutlarının çalışılması ve araştırılmasını bir gereklilik haline getirmiştir.

$\mathrm{Bu}$ çalışma, 21. yüzyıldaki çok boyutlu diplomasinin yeni unsurlarından biri olan dijital diplomasi kavramını tartışmalı ve vaka düzeyinde dijital diplomasinin bir alt türü olan Twitter diplomasisinin Türk-Amerikan ilişkilerindeki rolünü analiz etmeyi amaçladığından öncelikle bu iki kavramın nasıl tanımlandığı ve diğer diplomasi türleri ile nasıl farklılaştığını açıklamak gerekir. Dijital diplomasi, internet ve sosyal medya platformlarının kullanılması sebebiyle sıkça kamu diplomasisi ile karıştırılsa da aslında kamu diplomasisinin önemli bir parçası ve aracıdır. Kamu diplomasisi, devletlerin hem içeride hem de dişarıda geniş kitlelere ulaşmak ve bu kitlelerin düşüncelerini kendi çıkarları doğrultusunda etkilemek veya değiştirmek amacıyla radyo, televizyon, basın yayın organları, internet ve sosyal medya platformlarında yürüttükleri faaliyetleri de içeren kapsamlı bir etkileşim ve "diyalog"19 biçimidir. Dijital diplomasi ise internet ve sosyal medya platformlarının dış

13 Chirster Jönsson, Martin Hall, The Essence of Diplomacy, Hampshire, Palgrave Macmillan, 2005, s.26.

14 Ibid.

15 Costas Constantinou, Pauline Kerr, Paul Sharp, "Introduction: Understanding Diplomatic Practice", SAGE Handbook of Diplomacy, Londra, SAGE, 2016, s.4.

16 Literatürde "siber diplomasi kavramı" da dijital diplomasi yerine kullanılmaktadır. Bu konuda bir örnek için bkz. R.P Barston, Modern Diplomacy, Londra, Routledge, 2013, s. 112.

17 Ünlü diplomasisi (celebrity diplomacy), uluslararası kamuoyu tarafından tanınan kişilerin dünyayı ilgilendiren konularda farkındalığı arttırmak ve seferber edici bir etki yaratmak amacıyla faaliyetlerde bulunması olarak tanımlanmaktadır. Bu konuda ayrıntılı bir çalışma için bkz. Andrew F. Cooper, Celebrity Diplomacy, New York, Routledge, 2016.

18 Rana, küreselleşmenin dönüşümü kaçınılmaz ve zorunlu kıldığını, bu değişim ve dönüşümün en önemli ayaklarından birinin de internet ve dijitalleşme olduğunu ifade etmektedir. Kishan S. Rana, 21st Century Diplomacy: A Practitioner's Guide, Londra, The Continiuum Pub., 2011, p. 21.

19 Berridge ve Lloyd, diyalog kavramının kamu diplomasinin ayırt edici özelliği olduğunu, kamu diplomasisinin diyalog 
politika hedeflerine ulaşmak, daha görünür olmak, içerideki ve dışarıdaki hedef kitleye ulaşmak veya dış politika sorunlarını çözmek maksadıyla kullanılması şeklinde tanımlanabilir. ${ }^{20}$ Dijitalleşmenin diplomatik faaliyetler üzerindeki etkisini araştıran Gilboa’ya göre bu süreç Diplomasi 1.0 ve 2.0 olarak ikiye ayrılmaktadır. ${ }^{21}$ Diplomasi 1.0'da e-posta kullanımı ve internetteki içeriklerin tüketilmesi yoluyla yukarıdan aşağıya tek yönlü ve dikey bir iletişim vardır. ${ }^{22}$ Diplomasi 2.0 ise Twitter, Facebook, Instagram gibi sosyal medya platformlarının aktif kullanıldığı, iletişimin etkileşime dönüşürken yatay ve interaktif bir hal aldığı dönemi temsil etmektedir. ${ }^{23}$ Dijital diplomasi bu yönüyle hem kamu diplomasisinin hem de günlük rutin diplomatik faaliyetlerin önemli bir parçası olarak karşımıza çıkmaktadır.

Dijital diplomasinin bir alt kategorisi olarak Twitter diplomasisi, bir devleti, kurumu veya örgütü temsil eden kişilerin kişisel ve/veya kurumsal Twitter hesapları aracılığı ile dış politikaya dair öngörü, tutum ve beklentilerini sadece muhataplarına değil, tüm Twitter kullanıcılarına ilettikleri bir dış politika yürütme aracı olarak tanımlanabilir. Çalışmanın amacıyla da uyumlu olarak geliştirilen bu tanım üç önemli unsura vurgu yapmaktadır. Birincisi, Twitter diplomasisi kapsamında sadece devleti veya ilgili kurumu temsille yetkili kişilerin kişisel veya kurumsal hesaplar aracılığı ile attıkları tweetlerin dikkate alınması gerekliliğidir. İkincisi Twitter diplomasisinin yeni bir diplomasi türü olarak değil, yeni bir diplomasi yürütme aracı olarak tanımlanmış olmasıdır. Araştırmacılar ve diplomatlar da Twitter diplomasisi ile ayrı bir diplomasi türünü değil, Twitter'ın liderler ve bürokratlar tarafından bir diplomatik faaliyet aracı olarak kullanımını kastetmektedirler. ${ }^{24}$ Üçüncüsü hesaplardan gönderilen iletilere tüm kullanıcıların erişebilmesi nedeniyle, bu diplomasi aracının sadece ikili ilişkileri yürütmenin değil, kamu diplomasisi faaliyetlerinin de önemli bir parçası olduğunun altı çizilmiştir.

New York merkezli BCW İletişim Ajansı tarafından yapılan ve “Twiplomacy” başlığı ile internet kullanıcıları ile de paylaşılan kapsamlı araştırmaya göre, 2018 itibariyle 372'si kişisel, 579'u kurumsal olmak üzere toplam 951 Twitter hesabı, 187 ülkenin devlet ve hükümet başkanları ile dışişleri bakanları tarafından kullanılmaktadır. ${ }^{25}$ Bu hesaplar içinde aktif olarak kullanılan 107 dışişleri bakanı ve 131

aracılığı ile propaganda kavramından farklılaştığını iddia etmektedirler. Dictionary of Diplomacy, s. 305.

20 Sabrina Sotiriu, “Digital Diplomacy between Promises and Reality”, Corneliu Bjola ve Marcus Holmes (der.), Digital Diplomacy: Theory and Practice, Londra, Routledge, 2015, p. 35.

21 Eytan Gilboa, "Digital Diplomacy”, Costas M. Constantinou, Pauline Kerr, Paul Sharp (der.), SAGE Handbook of Diplomacy Londra, SAGE+, 2016. s. 542.

22 Ibid.

23 Ibid.

24 Rana, küreselleşmenin klasik diplomaside dönüşümü zorunlu kıldığını fakat sosyal medya platformları ve genel olarak internetin ancak mesleki eğitim sonrası "dikkatle kullanılması gereken araçlar" olduğunu ifade eder. Rana, 21st Century Diplomacy..., s. 207. 2009-2013 yılları arasında ABD Dışş̧leri Bakanlığı Başdanışmanı olarak görev yapan Alec J. Ross internet ve sosyal medyanın tıpkı "nükleer güce benzeyen bir araç” olduğunu ifade ederken, hükümetler tarafından doğru kullanımın kazanca, kötü kullanımın ise felakete yol açacağını söylemektedir. Eski İngiliz diplomat Carne Ross da konuya temkinli yaklaşan ve Twitter'ı basit bir diplomatik araç olarak tanımlayan uzmanlardandır. Ross'a göre Twitter ve Facebook gibi iletişim, müzakere ve diyalog içermeyen tek taraflı mesaj iletiminin ön planda olduğu platformlar diplomaside ancak bir "araç" olarak tanımlanabilir. 2007-2012 yılları arasında Meksika’nın ABD Büyükelçisi olarak görev yapan ve Twitter'ı diplomasi aracı olarak ilk kez kullanan yenilikçi diplomatlardan biri olan Arturo Sarukhan bile Facebook ve Twitter' ın diplomatik amaçlarla kullanımının klasik diplomasinin asla yerini alamayacağını ve bu platformlara "basit diplomatik araçlar" olmak dışında anlamlar yüklemenin gereksiz olduğunu savunmaktadır. Büyükelçilerin diplomasideki dijitalleşmeyi araç olarak tanımladıkları mülakatları için sırasıyla bkz. Andreas Sandre, Digital Diplomacy: Conversations on Innovation in Foreign Policy, Lanham, Rowman\&Littlefield, 2015, s. 10, s. 26 , s. 72.

25 Çalı̧̧maya dair detaylı bir özet için bkz. Twiplomacy 2018, "Executive Summary", 10 Temmuz 2018, https://twiplomacy. 
dışişleri bakanlığı hesabı bulunmakta olup, pek çok bakanlık da büyükelçilerini internette daha aktif olmaları yönünde teşvik etmektedir. ${ }^{26}$ Diplomasinin giderek daha çok kullanılan ve ilgi çeken bu yeni boyutunun, örnek olaylar üzerinden analizini yapmak hiç şüphe yok ki henüz gelişmekte olan yazına katkıda bulunacaktır. Fakat bulgu ve analizlerin anlam kazanabilmesi ve okuyucuyu ikna edebilmesi için önce kullanılacak yöntemin açıklanması ve gerekçelendirilmesi gerekmektedir.

\section{Yöntem}

Yöntemi açıklarken cevaplanması gereken ilk soru, ikili ilişkiler bağlamında ortaya konan araştırma sorularına hangi zaman diliminde cevap aranacağıdır. Araştırmanın amacı gereği incelenecek zaman dilimi, 8 Kasım 2016 ile 22 Ekim 2019 tarihleri arasındaki dönem ile sınırlandırılmıştır. İncelenen tarih aralığı Twitter diplomasisi üzerine bir araştırma için kısa gibi gözükse de, Twitter'ın TürkAmerikan ilişkilerinde bir diplomasi aracı olarak giderek daha fazla önem kazanması Başkan Trump döneminde gerçekleştiğinden, yukarıda belirtilen tarihler seçilmiştir. Öte yandan Trump’ın henüz yemin etmediği ve resmen başkanlık koltuğuna oturmadığı 8 Kasım 2016 tarihinin neden başlangıç tarihi olarak seçildiğini de açıklamak yerinde olacaktır. Dışişleri Bakanı Mevlüt Çavuşoğlu 9 Kasım 2016 tarihinde Trump'ın seçim zaferini bir Twitter mesajı ile kutlayarak ilişkileri geliştirme arzusunu vurgulamıştır. ${ }^{27} \mathrm{Bu}$ nedenle çalışmada Türk tarafının henüz yemin etmemiş olsa da 8 Kasım itibarıyla Trump'ı seçilmiş başkan olarak resmi muhatap kabul ettiği varsayılmış, araştırmanın başlangıç tarihi seçim sonucunun kesinleştiği 8 Kasım 2016 olarak belirlenmiştir.

Yöntem çerçevesinde cevaplanması gereken ikinci soru, belirtilen zaman aralığında incelenecek kişisel ve kurumsal hesapların hangi kriterlere göre seçildiği sorusudur. İncelenecek kişisel ve kurumsal hesaplar seçilirken, bir önceki bölümde çerçevesi çizilen Twitter diplomasisi tanımıyla tutarlı olabilmek için iki basamaklı bir eleme yapılmıştır. İlk basamakta seçim yapılırken kullanılan kriter, incelenecek hesapların devleti temsille yetkili karar alıcı ve/veya politika yürütücü gerçek kişi ve/veya kurumlara ait "resmi" hesaplar olmasıdır. İkinci basamakta ise birinci basamakta belirlenen resmi hesaplardan en etkili olanlarını incelemek amaçlanmış ve bu doğrultuda etki ölçümü yapılarak diğerlerine göre daha etkisiz resmi kişi ve kurum hesapları elenmiştir. Etki ölçümü neticesinde kişisel hesaplardan dört, kurumsal hesaplardan ise birer tanesi seçilerek bu hesaplardan atılan tweetler araştırmanın amaçları doğrultusunda mercek altına alınmıştır. Kurumsal hesapların birer adetle sınırlandırılmasının sebebi, dış politika ile ilgili bu hesaplardan atılan tweetlerin kişisel hesaplara nazaran kullanıcıların ilgisini daha az çekmeleri ve daha az etkiye sahip olmalarıdır. ${ }^{28}$

com/blog/twiplomacy-study-2018/, (Erişim Tarihi 21 Ağustos 2019).

26 Ibid.

27 @MevlutCavusoglu, ö.ö. 11:21, 9 Kasım 2016, “ABD’nin yeni Başkanı @realDonaldTrump’ı tebrik ediyoruz. $\mathrm{ABD}$ ile güvene dayalı stratejik işbirliğimizi güçlendirme arzusundayız”, https://twitter.com/MevlutCavusoglu/ status/796266500369879040 (Erişim Tarihi 21 Ekim 2019).

282018 yılını kapsayan Twiplomacy araştırmasına göre o yıl dünyada dış politika alanında en fazla etkileşim alan ve en fazla takipçi sayısına sahip ilk 15 hesap içerisine kurumsal olarak sadece Beyaz Saray @WhiteHouse ve Cumhurbaşkanlığı @tcbestepe resmi hesapları girebilmiştir. https://twiplomacy.com/ranking/50-world-leaders-interactions-twitter/, (Erişim Tarihi 27 Aralık 2019) ve https://twiplomacy.com/ranking/the-50-most-followed-world-leaders-in-2019/ (Erişim Tarihi 27 Aralık 2019). 
ABD tarafında, birinci basamaktaki "resmi hesap" kriterine göre ve 8 Kasım 2016 ile 22 Ekim 2019 tarihleri arasında görev yapmış olan Başkan, Başkan Yardımcısı, Dışişleri Bakanları Savunma Bakanları ve Ulusal Güvenlik Danışmanlarının kişisel ve resmi hesaplarının yanı sıra Beyaz Saray, Dışişleri Bakanlığı ve Savunma Bakanlığı’nın resmi kurumsal hesapları incelenmiştir. İkinci basamakta ise bu hesapların Twitonomy ${ }^{29}$ analiz aracı ile etki ölçümleri yapılmış ve diğerlerine göre düşük etkili kişisel ve kurumsal resmi hesaplar elenmiştir. Twitonomy analiz aracı, seçilen hesabın etkisini ölçerken ilgili hesabın toplam takipçi sayısı, tweet başına alınan ortalama beğeni sayısı ve RT sayısı ile toplam RT ve beğeni sayıları gibi çeşitli parametreler aracılığılla etkisi yüksek hesapların belirlenmesini sağlamıştır.

\section{ABD Tarafındaki Resmi Kişisel Hesapların Etki Ölçümleri}

\begin{tabular}{|c|c|c|c|c|c|c|c|c|c|c|}
\hline & 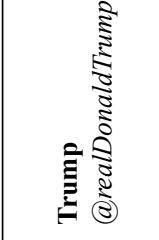 & 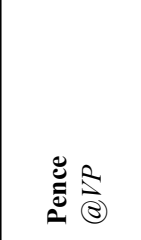 & 总 & 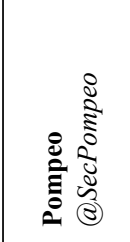 & 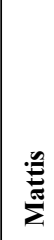 & 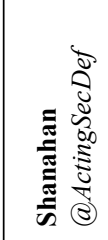 & 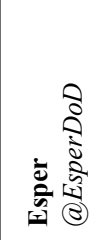 & 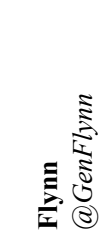 & 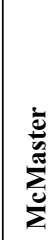 & 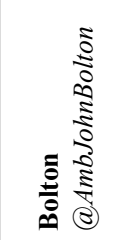 \\
\hline Takipçi sayısı & $67,958,379$ & $8,209,578$ & - & $\begin{array}{l}1,023, \\
135\end{array}$ & - & 33,554 & 56,971 & 293,033 & - & 859,794 \\
\hline $\begin{array}{l}\text { Gün başına atılan } \\
\text { ortalama tweet sayısı }\end{array}$ & 31.01 & 6.81 & - & 2.8 & - & 0.31 & 3.11 & 0.52 & - & 2.07 \\
\hline $\begin{array}{l}\text { Çekilebilen tweetlerin } \\
\text { sayısı }\end{array}$ & 3193 & 3200 & - & 1692 & - & 633 & 577 & 1678 & - & 3198 \\
\hline $\begin{array}{l}\text { Tweetlerinin RT } \\
\text { yapılma oranı }\end{array}$ & $\% 51,2$ & $\% 53,7$ & - & $\% 95,8$ & - & $\% 85$ & $\% 90,5$ & $\% 65,38$ & - & $\% 86,99$ \\
\hline $\begin{array}{l}\text { Alınan toplam RT } \\
\text { sayısı }\end{array}$ & $30.338,305$ & $3.165,571$ & - & $2,683,044$ & - & 43,938 & 76,776 & 560,040 & - & $2,034,002$ \\
\hline $\begin{array}{l}\text { Tweetlerinin } \\
\text { beğenilme Oranı }\end{array}$ & $\% 51,2$ & $\% 53,7$ & - & $\% 95.8$ & - & $\% 87,7$ & $\% 90,47$ & $\% 69,25$ & - & $\% 86,99$ \\
\hline $\begin{array}{l}\text { Alınan toplam beğeni } \\
\text { sayısı }\end{array}$ & $123,119,030$ & $13,705,407$ & - & $8,399,463$ & - & 142,354 & 271,511 & 812,478 & - & $4,811,632$ \\
\hline $\begin{array}{l}\text { Tweet başına alınan } \\
\text { ortalama RT sayısı }\end{array}$ & $18,555.54$ & 1843.66 & - & 1655.18 & - & 81.67 & 147.08 & 510.52 & - & 731.13 \\
\hline $\begin{array}{l}\text { Tweet başına alınan } \\
\text { ortalama beğeni } \\
\text { sayısı }\end{array}$ & $75,302.16$ & 7982.18 & - & 5181.66 & - & 256.49 & 507.14 & 699.21 & - & 1729.16 \\
\hline
\end{tabular}

29 Twitonomy, web tabanlı bir analiz aracı olup, https://www.twitonomy.com/ adresi üzerinden kullanıcılara hizmet vermektedir. İncelenen hesapların etkilerini en fazla son atılan 3200 tweet üzerinden ölçerek kullanıcılarına sunan Twitonomy analiz aracının ücretsiz ve ücretli olmak üzere iki farklı biçimi bulunmaktadır. Bu makaledeki verilere ulaşmak için ücretsiz versiyon kullanılmıştır. Güncelleme için yapılan son ölçüm 27 Aralık 2019 saat 13:27'de yapılmış olup, rakamlar gün ve saatlere göre değişim gösterebilir. 
ABD Tarafındaki Resmi Kurumsal Hesapların Etki Ölçümleri

\begin{tabular}{|c|c|c|c|}
\hline & $\begin{array}{l}\text { Beyaz Saray } \\
\text { @WhiteHouse } \\
\end{array}$ & $\begin{array}{c}\text { Dışişleri Bakanlığı } \\
\text { @StateDept }\end{array}$ & $\begin{array}{l}\text { Savunma Bakanlı̆̆ } \\
\text { @DeptofDefense }\end{array}$ \\
\hline Takipçi sayısı & $19,504,918$ & $5,503,999$ & $5,939,668$ \\
\hline $\begin{array}{l}\text { Gün başına atılan ortalama } \\
\text { tweet sayısı }\end{array}$ & 28.42 & 12.05 & 10.43 \\
\hline Çekilebilen tweetlerin sayısı & 3200 & 3200 & 3200 \\
\hline $\begin{array}{l}\text { Tweetlerinin RT yapılma } \\
\text { oranı }\end{array}$ & $\% 34,0$ & $\% 36,78$ & $\% 48,5$ \\
\hline Alınan toplam RT sayısı & $3,102,194$ & 327,326 & 377,613 \\
\hline Tweetlerinin beğenilme oranı & $\% 34,0$ & $\% 36,8$ & $\% 48,6$ \\
\hline Alınan toplam beğeni sayısı & $11,026,366$ & 782,528 & $1,287,732$ \\
\hline $\begin{array}{l}\text { Tweet başına alınan ortalama } \\
\text { RT sayısı }\end{array}$ & $2,848.66$ & 278.10 & 243.46 \\
\hline $\begin{array}{l}\text { Tweet başına alınan ortalama } \\
\text { beğeni sayısı }\end{array}$ & $10,125.22$ & 664.85 & 878.66 \\
\hline
\end{tabular}

Kişisel resmi hesaplar arasında sahip oldukları etki açısından ilk üç sırayı alan Başkan Donald Trump’a ait@realDonaldTrump, Başkan Yardımcısı Mike Pence'e ait @VP, Dışişleri Bakanı Pompeo’ya ait @SecPompeo ve eski Ulusal Güvenlik Danışmanı John Bolton’a ait @AmbJohnBolton hesapları ikinci basamak inceleme için seçilmiş, tablodaki diğer kişiler ise ya hesapları bulunmadığından ya da seçilenlere göre daha düşük etkiye sahip oldukları için inceleme dışında bırakılmışlardır. $\mathrm{Bu}$ noktada belirtmek gerekir ki, 1 Şubat 2017 ile 31 Mart 2018 tarihleri arasında Dışişleri Bakanlığı görevinde bulunan Rex Wayne Tillerson'un, 20 Şubat 2017 ile 23 Mart 2018 tarihleri arasında Ulusal Güvenlik Danışmanı olarak görev yapan Korgeneral H. R McMaster'ın ve 20 Ocak 2017 ile 31 Ocak 2018 tarihleri arasında Savunma Bakanı olarak görev yapan Jim Mattis'in kişisel Twitter hesapları bulunmadığından bu kişilere dair herhangi bir ölçüm yapılamamıştır. 24 Aralık 2018 ve 19 Haziran 2019 tarihleri arasında görev yapan Patrick Shanahan adına ise @ActingSecDef isimli arşivlenmiş bir hesap bulunmuş ve birinci basamak incelemeye dahil edilmiştir. Öte yandan, 10 Eylül 2019'da istifa eden John Bolton'un yerine yeni Ulusal Güvenlik Danışmanı olarak göreve başlayan Robert O'Brien'ın hesabı da incelenen zaman aralığı nedeniyle inceleme dışı bırakılmıştır. Bir önceki ABD Başkanı Barrack Obama tarafından kullanılan ve Başkan Trump’un kullanmayı reddettiği ${ }^{30} @ P O T U S$ hesabından herhangi bir veri alınamamış, veri çekmeyi sağlayan programların hiçbiri bu hesaptan veri çekmeyi başaramamıştır. Resmi kurumsal hesapların etki ölçümü yapıldığında ise ilk sırayı alan Beyaz Saray resmi hesabı @WhiteHouse incelemeye alınmıştır.

Türkiye tarafındaki hesapları seçerken de aynı süreç işletilmiştir. Birinci basamaktaki tek belirleyici olan "resmi hesap" kriterine göre ve 8 Kasım 2016 ve 22 Ekim 2019 tarihleri arasında görev yapmış olan Cumhurbaşkanı Recep Tayyip Erdoğan, Cumhurbaşkanı Yardımcısı Fuat Oktay, Dışişleri Bakanı Mevlüt Çavuşoğlu, Savunma Bakanları Fikri Işık, Nurettin Canikli, Hulusi Akar, Güvenlik ve Dış Politikalar Kurulu Başkanvekili İbrahim Kalın, Başdanışmanlar Gülnur Aybet, Sadık Arslan ve Mehmet Ferden Çarıkçı' ya ait resmi hesaplar incelemeye alınmıştır. Kurumsal olarak da Cumhurbaşkanlığı, Dışişleri Bakanlığı ve Millî Savunma Bakanlığı hesapları ilk basamakta incelenen hesaplar olmuştur. İkinci basamakta ise bu hesaplar içinden yine etki ölçümüne göre eleme yapılmıştır.

30 Daniel Halper, “Donald Trump won't be using the POTUS Twitter account”, New York Post, 16 Ocak 2017, https:// nypost.com/2017/01/16/donald-trump-wont-be-using-the-potus-twitter-account/, (Erişim Tarihi 11 Eylül 2019). 
Türkiye Tarafındaki Resmi Kişisel Hesapların Etki Ölçümleri

\begin{tabular}{|c|c|c|c|c|c|c|c|c|c|c|}
\hline & 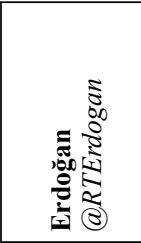 & 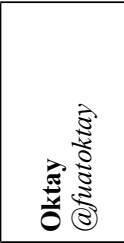 & 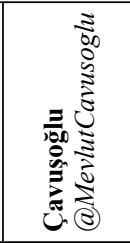 & $\frac{\sqrt{2}}{3}$ & 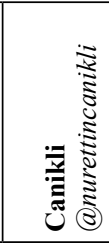 & $\stackrel{\vec{z}}{\dot{z}}$ & $\frac{\sqrt{\pi}}{\sqrt{\frac{\pi}{3}}}$ & 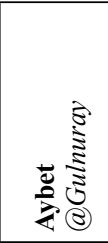 & 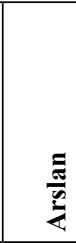 & 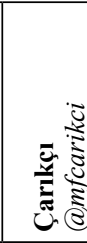 \\
\hline Takipçi sayısı & $14,419,955$ & 385,278 & $1,402,288$ & 587,099 & 214,057 & - & $1,541,141$ & 200,846 & - & 1546 \\
\hline $\begin{array}{l}\text { Gün başına } \\
\text { atılan ortalama } \\
\text { tweet sayıs1 }\end{array}$ & 1.67 & 1.27 & 4.75 & 2.89 & 1.99 & - & 1.22 & 2.71 & - & 13.33 \\
\hline $\begin{array}{l}\text { Çekilebilen } \\
\text { tweetlerin } \\
\text { sayis1 }\end{array}$ & 3200 & 1099 & 3200 & 3182 & 3113 & - & 3191 & 3182 & - & 3200 \\
\hline $\begin{array}{l}\text { Tweetlerin RT } \\
\text { Yapılma oranı }\end{array}$ & $\% 84,3$ & $\% 89,17$ & $\% 87,50$ & $\% 67,60$ & $\% 76,23$ & - & $\% 61,58$ & $\% 48,84$ & - & $\% 2.53$ \\
\hline $\begin{array}{l}\text { Alınan Toplam } \\
\text { RT sayis1 }\end{array}$ & $11,187,904$ & 210,498 & 683,969 & 165,404 & 100,039 & - & $1,383,482$ & 213,678 & - & 138 \\
\hline $\begin{array}{l}\text { Tweetlerin } \\
\text { beğenilme } \\
\text { oranı }\end{array}$ & $\% 84,3$ & $\% 89,17$ & $\% 87,53$ & $\% 67,66$ & $\% 77,03$ & - & $\% 61,70$ & $\% 50,63$ & - & $\% 5,81$ \\
\hline $\begin{array}{l}\text { Alınan toplam } \\
\text { beğeni sayısı }\end{array}$ & $41,507,752$ & $1,420,677$ & $3,314,230$ & 741,122 & 381,020 & - & $5,773,002$ & 700,948 & - & 408 \\
\hline $\begin{array}{l}\text { Tweet başına } \\
\text { alınan ortalama } \\
\text { RT sayısı }\end{array}$ & $4,146.74$ & 214.79 & 244.27 & 76.90 & 42.16 & - & 704.06 & 137.50 & - & 1.70 \\
\hline $\begin{array}{l}\text { Tweet başına } \\
\text { alınan ortalama } \\
\text { beğeni sayısı }\end{array}$ & $15,384.64$ & $1,449.67$ & $1,183.23$ & 344.23 & 158.89 & - & $2,931.95$ & 435.10 & - & 2.19 \\
\hline
\end{tabular}

Türkiye Tarafındaki Resmi Kurumsal Hesapların Etki Ölçümleri

\begin{tabular}{|c|c|c|c|}
\hline & $\begin{array}{c}\text { Cumhurbaşkanlığı } \\
\text { @tcbestepe }\end{array}$ & $\begin{array}{l}\text { Dışişleri Bakanlı̆̆ı } \\
\text { @TC_Disisleri }\end{array}$ & $\begin{array}{c}\text { Milli Savunma Bakanlığı } \\
\text { @tcsavunma }\end{array}$ \\
\hline Takipçi sayısı & $6,892,594$ & $1,357,036$ & 676,093 \\
\hline $\begin{array}{l}\text { Gün başına atılan ortalama } \\
\text { tweet sayısı }\end{array}$ & 5.19 & 4.03 & 3.37 \\
\hline Çekilebilen tweetlerin sayısı & 3200 & 3199 & 3200 \\
\hline Tweetlerin RT yapılma oranı & $\% 93,16$ & $\% 45,67$ & $\% 93,41$ \\
\hline Alınan Toplam RT sayısı & $2,811,574$ & 85,723 & 965,538 \\
\hline Tweetlerin beğenilme oranı & $\% 93,16$ & $\% 45,73$ & $\% 93,41$ \\
\hline Alınan toplam beğeni sayısı & $12,394,262$ & 85,723 & $5,650,344$ \\
\hline $\begin{array}{l}\text { Tweet başına alınan ortalama } \\
\text { RT sayısı }\end{array}$ & 943.16 & 58.67 & 323.03 \\
\hline $\begin{array}{l}\text { Tweet başına alınan ortalama } \\
\text { beğeni sayısı }\end{array}$ & $4,157.75$ & 131.85 & $1,890.38$ \\
\hline
\end{tabular}


Türkiye tarafındaki kişisel resmi hesaplara bakıldığında ilk dört sırayı alan Cumhurbaşkanı Recep Tayyip Erdoğan @RTErdogan, Güvenlik ve Dış Politikalar Kurulu Başkanvekili İbrahim Kalın @ikalin1, Dışişleri Bakanı Mevlüt Çavuşoğlu @MevlutCavusoglu ve Cumhurbaşkanı Yardımcısı Fuat Oktay’a ait @fuatoktay hesapları incelenen diğer hesaplara göre daha etkili olduklarından ikinci basamak sonunda incelenecek hesaplar arasına alınmış, diğer hesaplar elenmiştir. 10 Temmuz 2018'den bu yana Milli Savunma Bakanı olarak görev yapan Hulusi Akar’a ve Kasım 2016 ile Ocak 2019 arasında Cumhurbaşkanlığı Dışişleri Başdanışmanlığı görevinde bulunan Sadık Arslan’a ait resmi twitter hesapları bulunamadığından herhangi bir veri alınamamıştır. Resmi kurumsal hesaplar arasında ise Cumhurbaşkanlığı'na ait @tcbestepe hesabı Dışişleri ve Milli Savunma bakanlıklarına ait hesaplara nazaran en etkili hesap olarak seçilmiş ve diğer hesaplar ikinci basamakta elenmiştir.

İnceleme için seçilen kişilere ait tweetlerin bulunması ve incelenmesinde Twitter'ın ücretsiz olarak kullanıcılarına sunduğu "gelişmiş arama motoru" kullanılmıştır. Bu motorun parametreler kutularına incelenecek hesap, incelenecek tarih aralığı ve anahtar sözcük seti ile hangi dilde arama yapılacağı girilerek araştırma için gerekli verilere erişim sağlanmıştır. ${ }^{31}$ Belirtilen zaman aralığında Amerikan tarafındaki hesaplarda incelemeye konu edilen Türk-Amerikan ilişkilerine dair anahtar sözcük dizini “Turkey, Turkish, Ankara, US-Turkish, Erdogan, Cavusoglu, Kalin, Akar, Oktay, Isik, Canikli, Aybet, Arslan, Carikci” olarak belirlenmiş ve bu sözcüklerden en az birini içeren tweetler mercek altına alınmıştır. Bu sözcüklerin seçilme sebebi, ABD tarafındaki seçilmiş hesaplardan atılmış doğrudan muhatabını hedef alan Twitter mesajlarına ulaşmaktır. Türkiye tarafındaki hesapların içerikleri taranırken de anahtar sözcük dizini olarak "Amerika, ABD, Washington, Trump, Pence, TürkAmerikan, Pompeo, Tillerson, Flynn, McMaster, Bolton, Mattis, Shanahan ve Esper” kullanılmıştır. Bu sözcükler seçilirken de ikili ilişkiler bağlamında üstü kapalı veya ima yoluyla mesajlar veren tweetlere değil, doğrudan muhatapları hedef alan tweetlere erişim sağlamak amaçlanmıştır. ${ }^{32}$

Twitter'ın diplomasisinin "muhataba mesaj iletmek” ve kamuoyu desteği kazanmak” olarak belirtilen çift yönlü işlevini anlayabilmek için Türkiye tarafındaki seçilmiş hesaplar taranırken özel isimlere ve Türkçe sözcüklere ek olarak "USA", “Turkish-American” ve "Turkey-US” ifadelerini içeren İngilizce tweetler de aranmıştır.

\section{Bulgular}

Çalışmanın giriş bölümünde belirtilen ilk araştırma sorusu olan "araştırma için seçilen politik figürler Twitter'ı ikili ilişkiler bağlamında nasıl ve hangi gündem başlıklarında kullanmaktadırlar?” sorusuna cevap bulabilmek için ilk olarak belirlenmiş sözcük dizinindeki kelimelerden en az biri, yine yöntem bölümünde açıklanan zaman aralığında taranmıştır. ABD tarafındaki hesaplar incelendiğinde anahtar sözcük dizinindeki en az bir sözcüğü içeren ve bunların içinde doğrudan Türk Amerikan ilişkileri ile ilgili olan tweet sayıları şu şekildedir;

31 Twitter'ın gelişmiş arama ara yüzünün araştırmacılar tarafından nasıl kullanılacağına dair ayrıntılı bir bilgi için bkz. Twitter Yardım Merkezi, Arama ve Gündemler, “Gelişmiş aramayı kullanma”, https://help.twitter.com/tr/usingtwitter/twitter-advanced-search (Erişim Tarihi 22 Ekim 2019).

32 Örnek vermek gerekirse, 26 Temmuz 2018'de Trump ve Pence'in Brunson Davası konusunda Türkiye'yi doğrudan tehdit eden mesajlarına Dışişleri Bakanı Çavuşoğlu "Hiç kimse bize talimat veremez. Kimsenin tehdidine de boyun eğecek değiliz. Hukuk kuralları istisnasız herkes için geçerlidir” tweetiyle karşılık vermiştir. Bakanın bu tweetinde muhatap belli olsa bile ima bulunduğundan ve anahtar sözcüklerden herhangi birini içermediğinden, ima yollu mesaj içeren tweetlerin tümü gibi inceleme dışı bırakılmıştır. 
Tablo 2.1 ABD tarafindaki tweet sayıları

\begin{tabular}{|l|c|c|}
\hline & En az bir anahtar sözcük barındıran tweetler & $\begin{array}{c}\text { En az bir anahtar sözcük barındıran tweetler } \\
\text { içinde Türk-Amerikan ilişkilerine dair tweetler }\end{array}$ \\
\hline $\begin{array}{l}\text { Trump } \\
\text { @realDonaldTrump }\end{array}$ & 48 & 40 \\
\hline $\begin{array}{l}\text { Pence } \\
\text { @VPP }\end{array}$ & 21 & 21 \\
\hline $\begin{array}{l}\text { Pompeo } \\
\text { @SSecPompeo }\end{array}$ & 18 & 18 \\
\hline $\begin{array}{l}\text { Bolton } \\
\text { @.AmbJohnBolton }\end{array}$ & 9 & 9 \\
\hline $\begin{array}{l}\text { White House } \\
\text { @WhiteHouse }\end{array}$ & 33 & 7 \\
\hline
\end{tabular}

Görüldüğü üzere Amerikan tarafında ikili ilişkilere dair tweet atanlar içinde, liderlik toplam 40 tweet ile Başkan Trump'tadır ve onu toplam 21 tweetle Başkan Yardımcı Pence izlemektedir. Başkanla kıyaslandığında araştırma için seçilen bakan ve bürokratların Twitter'ı ikili ilişkiler bağlamında çok az kullandıkları veya Tillerson, McMaster ve Mattis örneklerinde olduğu gibi hiç kullanmadıkları görülmektedir. Beyaz Saray kurumsal hesabından da ikili ilişkilere dair atılan tweet sayısının son derece az olduğu anlaşılmıştır.

Tablo 2.2 Türkiye tarafındaki tweet sayıları

\begin{tabular}{|l|c|c|}
\hline & $\begin{array}{c}\text { En az bir anahtar sözcük barındıran } \\
\text { tweetler }\end{array}$ & $\begin{array}{c}\text { En az bir anahtar sözcük barındıran tweetler } \\
\text { içinde Türk-Amerikan ilişkilerine dair tweetler }\end{array}$ \\
\hline $\begin{array}{l}\text { Erdoğan } \\
\text { @RTErdogan }\end{array}$ & 16 & 15 \\
\hline $\begin{array}{l}\text { Çavuşoğlu } \\
\text { @MevlutCavusoglu }\end{array}$ & 174 & 137 \\
\hline $\begin{array}{l}\text { Kalın } \\
\text { @ikalin1 }\end{array}$ & 31 & 30 \\
\hline $\begin{array}{l}\text { Oktay } \\
\text { @fuatoktay }\end{array}$ & 4 & 4 \\
\hline $\begin{array}{l}\text { Cumhurbaşkanlığı } \\
\text { @ tcbestepe }\end{array}$ & 123 & 116 \\
\hline
\end{tabular}

Türkiye tarafına bakıldığında ise Twitter'ın ikili ilişkileri yürütürken Amerikan tarafına nazaran daha aktif biçimde kullanılan bir araç olduğu görülmektedir. Cumhurbaşkanlığı kurumsal hesabı @ tcbestepe, Dışişleri Bakanı @MevlutCavusoglu ve @ikalin1 kişisel hesaplarının ABD tarafında onlara karşılık gelen@WhiteHouse, @SecPompeo ve@AmbJohnBolton hesaplarına göre Twitter'ı ikili ilişkiler bağlamında çok daha sık kullandıkları ortaya çıkmıştır. Elbette her iki tarafta yer alan bu sayıların anlamlı bulgular haline dönüşmesi için atılan tweetlerin ikili ilişkilerdeki hangi gündem başlıkları ile ilgili olduğunun bilinmesi gerekir. Türk-Amerikan ilişkilerinde incelenen döneme ait başlıkların birbirinden tamamen bağımsız olmadığı ve tam tersine iç içe geçmiş bir sorunlar kümesinin gündem maddeleri olduğu bilinmektedir. Ancak çalışma, yöntem bölümünde de açıkça belirtildiği gibi, tek bir 
konu üzerine muhatabını doğrudan hedef alan tweetler üzerinden içerik analizi yaptığından konuların sınıflandırılması da bu çerçevede değerlendirilmelidir. ${ }^{33}$

Tablo 2.3 ABD tarafindaki tweet konuları

\begin{tabular}{|l|c|c|c|c|c|c|c|}
\hline & $\begin{array}{c}\text { PYD, YPG } \\
34\end{array}$ & DAEŞ ${ }^{35}$ & $\begin{array}{c}\text { Brunson } \\
\text { Davasi }^{36}\end{array}$ & Duyurular ${ }^{37}$ & Kibrıs & Diğer $^{38}$ & TOPLAM \\
\hline $\begin{array}{l}\text { Trump } \\
\text { @realDonaldTrump }\end{array}$ & 17 & 6 & 9 & 5 & - & 3 & 40 \\
\hline $\begin{array}{l}\text { Pence } \\
@ \text { VPP }\end{array}$ & 3 & 1 & 12 & 2 & 2 & 1 & 21 \\
\hline $\begin{array}{l}\text { Pompeo } \\
\text { @SecPompeo }\end{array}$ & 6 & - & 5 & 4 & - & 3 & 18 \\
\hline $\begin{array}{l}\text { Bolton } \\
\text { @AmbJohnBolton }\end{array}$ & 1 & 2 & - & 4 & - & 2 & 9 \\
\hline $\begin{array}{l}\text { White House } \\
\text { @WhiteHouse }\end{array}$ & 3 & - & 1 & 2 & - & 1 & 7 \\
\hline
\end{tabular}

33 Anahtar kelimeleri içeren tweetler konu bazında kategorilere ayrılırken iki kişi tarafından hem ayrı ayrı hem de müşterek olarak okunmuştur. Bu noktada yardımlarından ötürü Araş. Gör. Tuğcan Durmuşlar’a teşekkür ederim. Tweetlerin kodlanması sırasında okuma sıralaması, tarih olarak en yeniden en eskiye doğru yapılmıştır. Tek bir konu başlığı içeren tweetler ilgili kategorilerde kodlanırken, birden fazla konu başlığı içeren tweetler olası sübjektif değerlendirmelerin önüne geçmek için “Diğer” kategorisinde kodlanmıştır. Her kategorinin kapsadığı konular ve kişilere dair açıklayıcı dipnotlar ilgili kategorinin yanında sunulmuştur.

34 PYD (Partiya Yekîtiya Demokrat / Demokratik Birlik Partisi) ve YPG (Yekîneyên Parastina Gel / Halk Savunma Birlikleri) Suriye'de faaliyet gösteren ve Türkiye tarafından terör örgütü PKK’nın (Partiya Karkerên Kurdistanê / Kürdistan İşçi Partisi) Suriye kolu olarak nitelenen siyasi ve askeri yapılardır. ABD’nin Suriye sahasında mücadele kapsamında PYD ve YPG ile 2015 yılından bu yana sürdürdüğü iş birliği, Türkiye tarafından defalarca protesto edilmiş ve bu konu ikili ilişkilerin en problemli gündem başlıklarından biri haline gelmiştir. ABD tarafındaki hesaplardan atılan anahtar sözcükleri içeren tweetlerde terör örgütünün yukarıda bahsedilen isim ve kısaltmalarının kullanılmadığı, bunun yerine Suriye Kürtlerinin geneli kastedilerek Kurds "Kürtler” sözcügünün veya SDF (Syrian Democratic Forces / Suriye Demokratik Güçleri) kısaltmasının tercih edildiği görülmüştür.

35 Dawlah al-Islamiyah fil-'Iraq wa ash-Sham, (Irak-Şam İslam Devleti), Türk yetkililer tarafından Arapça kısaltmasının Latin harfleriyle yazılışı olan DAEŞ ve/veya DEAŞ olarak kullanılırken, ABD tarafinda Islamic State of Iraq and Syria (Irak ve Suriye İslam Devleti) kısaltması olan ISIS kullanılmaktadır.

369 Aralık 2016'da İzmir'deki Protestan cemaatine ait Diriliş Kilisesi'nin rahibi Andrew Brunson, FETÖ soruşturması kapsamında bir gizli tanığın aleyhine verdiği ifade gerekçe gösterilerek tutuklanmıştır. 35 yıl hapis istemiyle yargılanan Brunson, PKK ve FETÖ adına propaganda yapmak ve suç işlemekle suçlanmıştır. 25 Temmuz 2018 'de tutukluluk hali sağlık sorunları gerekçesiyle ev hapsine çevrilen Brunson, toplamda 3 yıl 1 ay 15 gün hapis cezasına çarptırılmıştır. Tutuklu kaldığı zaman göz önüne alınarak tahliye edilen Brunson, 12 Ekim 2018'de ülkesine dönmüştür. Dava 2016 ve 2018 yılları arasında Türk-Amerikan ilişkilerinin en sorunlu gündem maddesi haline dönüşmüş ve ABD tarafının Twitter üzerinden yürüttüğü bir kampanyanın da merkezine yerleşmiştir.

37 Bu kategori hem ABD hem de Türkiye tarafında tekli veya çoklu gündem başlıkları etrafında yapılan rutin veya rutin dışı genel görüşme duyurularını, heyetler veya kişiler arası toplantı, ziyaret ve telefon görüşmesi duyurularını, resmi veya gayri resmi yemek, resepsiyon, kokteyl vb. duyuruları, basın mensuplarına verilen mülakat duyurularını, ilgili ülkenin basın yayın organlarında seçilen siyasi figürler tarafından yayınlanan makale ve mülakat duyurularını, düşünce kuruluşları toplantıları duyurularını, kanaat önderleri ile yapılan toplantı duyurularını, basın toplantısı duyurularını ve lobi faaliyetleri duyurularını içermektedir. Tek bir gündem maddesi konusunda doğrudan muhatabını hedef alarak hükümetin fikir, tutum ve beklentilerini ifade eden tweetler ise ilgili sütunlara yerleştirilmiştir.

38 Bu kategori hem ABD hem de Türkiye tarafında, birden fazla gündem başlığını içerdiğinden diğer tekli kategorilere yerleştirilemeyen tweetleri ve terör saldırılarını kınama / başsağlığı mesajları ile çeşitli tebrik mesajlarını içermektedir. 
Yukarıdaki tablodan anlaşılabileceği üzere, ABD tarafında atılan tweetlere dair ilk bulgular Twitter diplomasisinin gündemine dikkat çekmektedir. Twitter diplomasisi çerçevesinde el alınan konular arasında birinci sırayı, ABD-PYD/YPG ilişkisi ile bu ilişki çerçevesinde ABD'den Türkiye'ye yöneltilen eleştiri ve tehditler almaktadır. Başkan Trump'ın Amerikan askerlerini Suriye'nin kuzeydoğusundan çekme kararı almasının ardından Türkiye’nin PYD/YPG'ye yönelik başlattığı Barış Pınarı Harekâtı, ikili ilişkilerin ABD tarafındaki en önemli başlık olmuştur. Twitter diplomasisi gündeminin ikinci sırasını ise Rahip Brunson davası almıştır. Gerek Trump gerekse Pompeo'nun Rahip Brunson davasını yakından takip ettikleri ve bu konunun ikili ilişkilere dair attıkları tweetlerde ikinci sırayı aldığı görülmektedir. Başkan Yardımcısı Pence'in tweetlerinde ise Brunson davası Suriye, PKK ve DAEŞ gibi konuların önüne geçerek ilk sırayı almıştır. İkinci önemli bulgu ise, karşı tarafı doğrudan hedef alan ve tek bir konu üzerinden muhatabına mesaj ileten mesajların ağırlıkla Başkan Trump’a ait olmasıdır. Başkan'ın doğrudan Türkiye'yi hedef alan ve tek bir konu başlığı içeren 32 tweetine karşılık, Pence'in 16, Pompeo'nun 11, Bolton'un 3 tweeti bulunmaktadır. Üçüncü önemli bulgu, iki ülke arasındaki gerilimi yüksek gündem başlıkları olan, Ankara'nın S-400 füze savunma sistemleri alım kararı, Hakan Atilla Davası veya Fethullah Gülen'in Türkiye'ye iadesinin Amerikan tarafında tek bir konu başlı̆̆ içeren tweetlerin hiçbirisine konu edilmemiş olmasıdır. Bir başka deyişle, ABD tarafında incelenen hesaplar, Amerikan kamuoyunun yakından takip ettiği ve Trump yönetiminin iç politika malzemesi haline getirdiği Amerikan askerlerinin Suriye'nin kuzeydoğusundan çekilmesi ile Brunson Davası dışındaki konulara Twitter üzerinden değinmemeyi tercih etmişlerdir.

Türkiye'deki seçilmiş hesaplar tarafından atılan ve anahtar sözcüklerden en az birini içeren tweetlere bakıldığında ise başka bir tabloyla ve farklı bulgularla karşılaşılmıştır. 
Tablo 2.4 Türkiye tarafındaki tweet konuları

\begin{tabular}{|c|c|c|c|c|c|c|c|c|c|c|c|c|c|c|c|}
\hline & $\begin{array}{l}0 \\
\vdots \\
\vdots \\
\vdots \\
\vdots\end{array}$ & 留 & 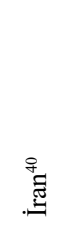 & 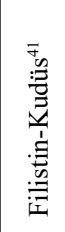 & 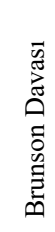 & $\begin{array}{l}\frac{7}{5} \\
\frac{7}{1} \\
\stackrel{0}{7} \\
>\end{array}$ & 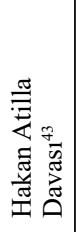 & 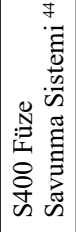 & 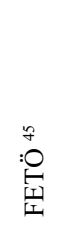 & 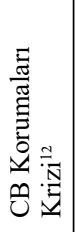 & 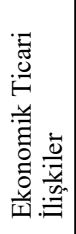 & 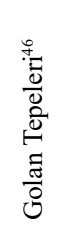 & 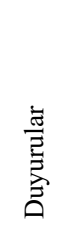 & 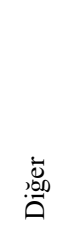 & $\frac{\text { ज्ञ }}{\text { के }}$ \\
\hline $\begin{array}{l}\text { Erdoğan } \\
\text { @RTErdogan }\end{array}$ & - & - & - & 4 & 1 & - & - & - & - & - & - & - & 9 & 1 & 14 \\
\hline $\begin{array}{l}\text { Çavuşoğlu } \\
\text { @ } \text { MevlutCavusoglu }\end{array}$ & - & - & 1 & 5 & 1 & - & - & - & 2 & 1 & 1 & 2 & 118 & 6 & 137 \\
\hline $\begin{array}{l}\text { Kalın } \\
\text { @ikalin1 }\end{array}$ & 1 & - & 2 & 9 & 1 & 1 & - & - & 1 & - & - & 2 & 4 & 9 & 30 \\
\hline $\begin{array}{l}\text { Oktay } \\
@ \text { fuatoktay }\end{array}$ & - & - & - & 1 & & - & - & - & - & - & 1 & - & 1 & 1 & 4 \\
\hline $\begin{array}{l}\text { Cumhurbaşkanlığ } \\
\text { @ tcbestepe }\end{array}$ & 15 & & 4 & 8 & 2 & 4 & 3 & 1 & 3 & - & - & - & 65 & 11 & 116 \\
\hline
\end{tabular}

Tabloda ilk göze çarpan bulgu, Türkiye tarafındaki hesapların tweetlerinde ziyaretler, toplantılar, telefon görüşmeleri ve basın toplantılarını konu alan duyuruların ilk sırayı almasıdır. İkinci sırayı, birden fazla konu başlı̆g i çerdiği için herhangi bir tekli kategoriye yerleştirilemeyen tweetler ile "Filistin-Kudüs" konulu tweetler paylaşmaktadır. Duyuruların ve "diğer" kategorisine ayrılan tweetlerin ağırlıklı olarak @tcbestepe ve @MevlutCavusoglu hesaplarından gönderildiği görülmüştür. İkinci önemli bulgu ise doğrudan muhatabın hedef alındığı ve tek bir konu içeren tweetlerin en çok @tcbestepe ve @ikalin1 hesaplarından atılmasıdır. Üçüncü önemli bulgu ise, ABD tarafından

39 ABD yönetiminin İran'la Nükleer Anlaşma'dan çekilmesi ve bu kapsamda uygulamaya koyduğu yaptırımlara yönelik Türk tarafından atılan tweetler bu kategoride değerlendirilmiştir.

40 Türk tarafının ABD’nin İsrail Büyükelçiliği'nin Kudüs'e taşıma kararı ve Filistin sorunu çerçevesinde İsrail'e destek veren politikalarını hedef alan tweetleri bu kategoriye yerleştirilmiştir.

41 ABD İstanbul Başkonsolosluğu çalışanlarından Metin Topuz, 4 Ekim 2017 tarihinde askeri ve siyasal casusluk suçlamasıyla tutuklanmış ve bu olay ABD'nin 8 Ekim 2017'de Türkiye'den yapılan vize başvurularını süresiz askıya almasıyla krize dönüşmüştür. 28 Aralık 2017'de ABD tarafı, Türkiye'ye yönelik tüm vize kısıtlamalarını kaldırırken bu olay ulusal ve uluslararası basında "Vize Krizi" olarak isimlendirilmiştir.

42 Halkbank’’n eski genel müdür yardımcısı Hakan Atilla, Mart 2017'de gerçekleştirdiği ABD ziyareti sırasında tutuklanmış, ABD’nin İran yaptırımlarını delmek ve çeşitli mali suçlar işlemekle suçlanarak 32 ay hapis cezasına çarptırılmıştır. Davadaki duruşmalar sırasında, tanık ifadelerinde Cumhurbaşkanı Recep Tayyip Erdoğan, eski Başbakan Yardımcısı Ali Babacan ve eski Halkbank Genel Müdürü Süleyman Aslan'ın isimlerinin geçmesi iki ülke arasında krize neden olmuştur. Hakan Atilla jüri tarafindan suçlu bulunarak 28 ay hapis yattıktan sonra 24 Temmuz 2019'da tahliye edilerek Türkiye'ye gönderilmiştir.

43 Türkiye'nin Rusya'dan almayı planladığı S-400 hava savunma sistemleri ve bununla ilgili ABD yaptırımlarını konu eden tweetler bu kategoride değerlendirilmiştir.

44 Türkiye tarafından terör örgütü ilan edilen yapılanma, Fethullahçı Terör Örgütü sözcüklerinin kısaltılmasıyla FETÖ olarak isimlendirilmiştir. FETÖ kategorisi, Türkiye tarafında atılan Fethullah Gülen'in ABD tarafından himayesi ve Türkiye'ye iadesi ile ilgili tweetleri içermektedir.

45 Cumhurbaşkanı Erdoğan'ın Mayıs 2017'deki ABD ziyareti sırasında Türkiye Büyükelçiliği konutu önünde bulunan protestocularla karşıt görüşteki Türkler ve Cumhurbaşkanlığı koruma memurları arasında arbede çıkmıştır. Protestocuların korumalar tarafından darp edilme görüntülerinin basına yansıması üzerine Washington D.C. Savcılığı, aralarında 12 Cumhurbaşkanlığı korumasının da bulunduğu toplam 19 kişi hakkında "nefret suçuyla artırılmış şiddet suçu işlemeye teşebbüsten” yargılama yapılmasına karar vermiştir. Bu konudaki tek tweetin tutuklanan iki Türk'ü ABD’deki hapishanede ziyaret eden Mevlüt Çavuşoğlu tarafindan atıldığı görülmektedir.

4625 Mart 2019'da Başkan Donald Trump’ın Golan Tepelerinin İsrail toprağı olduğu iddiasını içeren bir kararnameyi imzalaması üzerine Türk tarafında incelenen hesaplardan atılan ve kararı eleştiren tweetler bu kategoriye yerleştirilmiştir. 
atılan tweetlerin genelinde rastlanmayan konu çeşitliliğidir. Türkiye tarafında incelenen hesapların tweetlerinde Fethullah Gülen' in Türkiye'ye iadesinden ABD'nin İran politikası ve ilgili yaptırımlarına, 2017’nin sonuna doğru patlak veren vize krizinden ABD yönetiminin Tel Aviv'deki büyükelçilik binasını Kudüs'e taşıma kararına kadar pek çok konuya rastlanmıştır. Bu konular arasında 26 tweetle Filistin ve Kudüs meselesi, 16 tweetle de ABD'nin PYD ve YPG ile yürüttüğü iş birliği, "duyurular” ve "diğer" kategorileri ile birlikte en sık rastlanan konu başlıkları olmuştur.

Çalışmanın ikinci araştırma sorusu olan “inceleme için seçilen figürler Twitter'ı ikili ilişkiler bağlamında hangi amaçla kullanmaktadırlar” sorusuna da bulgulardan yola çıkarak cevap vermek mümkündür. Kavramsal çerçeve çizilirken Twitter'ın hem kamu diplomasisinin hem de ikili ilişkileri yürütmenin bir aracı olduğuna dikkat çekilmiştir. Twitter’a yüklenen bu işlev, bu sosyal medya platformunun diş politikadaki kullanım amaçlarında da kendini belli etmektedir. Örneğin, ABD tarafından atılan tweetler içerisinde toplam 30 adet tweetle ilk sırayı alan ABD ile PYDYPG ilişkisi esasen ABD’nin Twitter'ı hem kamu diplomasisi hem de ikili ilişkiler çerçevesinde nasıl kullandığını açıkça göstermektedir. Başkanlık kampanyası boyunca ve başkanlığı sırasında ABD askerlerini ülkenin hayati çıkarlarının olmadığı çatışma bölgelerinden çekme sözü veren Trump, attığı tweetlerle bir yandan Türkiye'yi tehdit etmekte, bir yandan da Amerikan kamuoyunu kazanmayı hedeflemektedir. Bu kategori altındaki tweetler her ne kadar ABD’nin kuzeydoğu Suriye'den çekilme kararının ardından Türkiye'nin PYD-YPG'ye yönelik askeri operasyonuna engel olmak amacıyla atılmış olsa da olayların 2020 Başkanlık seçimleri ve Amerikan kamuoyuna yönelik boyutu da gözden kaçmamalıdır.

Konular sıralamasında toplam 27 tweetle ikinci sırayı alan Rahip Brunson davası, Twitter'n Washington tarafından hem kamu diplomasisi yürütmek hem de ikili ilişkilere dair doğrudan mesaj iletmek amaçlarıyla nasıl kullanıldığını gösteren ikinci örnek olaydır. Başkan Trump,${ }^{47}$ Dışişleri Bakanı Pompeo $^{48}$ ve bu araştırmaya dahil edilmeyen Başkan Yardımcısı Pence'in ${ }^{49}$ Brunson davası ile ilgili tehditkâr tweetleri, hem Amerikan kamuoyunu hedefleyerek muhafazakâr seçmeni yönetim etrafında kenetlemeyi ve seferber etmeyi, hem de Türk hükümeti üzerinde doğrudan baskı oluşturmayı amaçlamıştır. ABD yönetiminin Rahip Brunson'ın Türkiye'den ayrıldığı andan Beyaz Saray'da Trump'la buluşmasına kadar geçen neredeyse her dakikayı, Twitter üzerinden yürütülen görsel bir kampanyaya çevirmesi, ülkedeki muhafazakâr seçmenleri kazanmasını sağlamış, Türkiye tarafından yükselen sert tepkiler de ABD tarafından verilen doğrudan mesajın Ankara'da hedefine ulaştığını göstermiştir.

47 @realDonaldTrump, ö.s. 6:22, 26 Temmuz 2018, "Birleşik Devletler, harika bir Hristiyan, bir aile adamı ve muhteşem bir insan olan Pastör Brunson'ın uzun süren tutukluluk sürecinden ötürü Türkiye'ye büyük yaptırımlar uygulayacak. Büyük bir acı çekiyor. Bu masum adam acilen serbest bırakılmalı!”, https://twitter.com/realDonaldTrump/ status/1022502465147682817 (Erişim Tarihi 28 Ağustos 2019).

48 @SecPompeo, ö.s. 11:48, 13 Ekim 2018, “Oval Ofiste Pastör Brunson’ı selamlamak için @POTUS’a eşlik etmekten onur duyuyorum. İnancını özgürce icra edebileceği evinde, ABD’de olmasından memnunum. Türkiye’yi haksız biçimde tutuklanmış tüm Amerikalıları ve oradaki temsilciliğimiz tarafından işe alınan yerel görevlileri serbest bırakmaya çağırıyorum”, https://twitter.com/SecPompeo/status/1051213076182249472 (Erişim Tarihi 28 Ağustos 2019).

49 @VP, ö.s. 5:49, 26 Temmuz 2018, "ABD Başkanı adına Cumhurbaşkanı Erdoğan ve Türk hükümetine bir mesajım var. Pastör Brunson'ı ŞİMDİ serbest bırakın ya da sonuçlarıyla yüzleşmeye hazırlıklı olun”, https://twitter.com/VP/ status/1022494110735851521 (Erişim Tarihi 28 Ağustos 2019). 
Türkiye tarafında atılan mesajlarda ilk sırayı alan rutin veya rutin dışı kamuoyunu bilgilendirme mesajları dışındaki çeşitlilik, Ankara’nın Twitter'ı tıpkı Washington gibi hem kamu diplomasisi hem de ikili ilişkileri yürütme amacıyla kullandığını göstermektedir. Türk tarafı, konular dizininde sayı olarak ikinci ve üçüncü sırayı alan Filistin/Kudüs meselesi ve PKK/PYD/YPG konusu ile hem Washington’a ABD’nin Ortadoğu politikaları konusundaki rahatsızlığını doğrudan iletmiş, hem de içerideki milliyetçi-muhafazakâr seçmeni hükümet etrafında kenetlenmeye davet etmiştir. Hakan Atilla Davası, FETÖ liderinin Türkiye'ye iadesi ve vize krizi gibi gündem başlıkları ile de benzer amaçların hedeflendiğini söylemek yanlış olmayacaktır. Öte yandan, ABD tarafından farklı olarak Türk tarafından atılan tweetlerdeki Filistin-Kudüs ve Golan Tepeleri ile ABD’nin İran politikalarına yönelik mesajlar, hükümetin sadece Türk kamuoyundaki muhafazakâr-milliyetçi kitleye yönelik değil, tüm Ortadoğu halkları arasında zemin kazanmaya yönelik bir kamu diplomasisi hamlesi olarak da okunabilir. Şahsi hesabını dış politika krizleri için çok sık kullanmayan Cumhurbaşkanı Erdoğan’ın bile bu hesaptan takipçilerine Kudüs ve Filistin meselesine dair mesajlar vermesi, İbrahim Kalın'a ait kişisel hesabın ve Cumhurbaşkanlığı resmi Twitter hesabının da yine aynı konu hakkında sıkça kullanılması, Ankara'nın hem ABD’ye mesaj vermeyi hem de Ortadoğu halkları arasında zemin kazanmayı amaçladığını göstermektedir. ${ }^{50}$

Çalışmanın ana tartışma konusu "Twitter diplomasisinin Türkiye-ABD ilişkilerine etkisi” olduğundan, Twitter'ın kamu diplomasisi amacıyla kullanımından ziyade 280 karaktere sığdırılan ve doğrudan muhatabı hedef alan mesajların ikili ilişkilerdeki olumlu veya olumsuz etkilerine de bakmak gerekmektedir. Bu amaçla gelecek bölümde çalışmanın üçüncü araştırma sorusu olan Twitter'ın ikili ilişkilerdeki rolü nedir ve gelecekte ne olacaktır sorularına bu temel tartışma konusu kapsamında cevap aranacaktır. $\mathrm{Bu}$ amaçla ortaya konacak analiz, öngörü, tespit ve karar alıcılar için politika tavsiyeleri sadece yukarıdaki bulguların yorumlanmasını değil, yetkili kişilerin konu üzerine verdikleri demeçlerin, mülakatların ve mevcut yazının da yeniden incelenmesini gerektirmektedir.

\section{Bugün ve Gelecekte Twitter Diplomasisi}

Twitter ve diğer sosyal medya platformlarının klasik diplomasiyi, giriş bölümünde altı çizilen çeşitli değişimlere zorladığı aşikardır. Bunlar arasında klasik diplomasinin asırlar süren pratikler neticesinde örülmüş gizlilik duvarının çatlaması, şeffaflı̆̆ın yeni diplomasinin giderek ön plana çıan özelliklerinden biri haline gelmesi, diplomatlar ve politikacılar dışındaki aktörlerin de kapsayıcı bir diplomasi anlayışıyla denkleme dahil olması ve zaman-mekân kavramlarının ortadan kalkması ile iletişimin kolaylaşması olumlu değişimler olarak sayılabilir. Hatta sadece olumlu değişimler tarafından bakılırsa, Twitter'ın "kolaylaştırıcı" bir dış politika yürütme aracı olduğu sonucuna da varılabilir. Fakat Türk-Amerikan ilişkileri özelinde incelenen hesaplar ve mesajlar mercek altına alındığında Twitter'ın kolaylaştırıcı olmaktan çok sorun çıkarıcı, kriz büyütücü ve zorlaştırıcı bir dış politika aracı haline dönüştüğü görülmektedir. Bu iddiada bulunurken, aslında gerçek sorumlunun Twitter değil

50 Çalışmanın kapsamı dışında kalmakla birlikte, 8 Kasım 2016-22 Ekim 2019 tarihleri arasında İbrahim Kalın’a ait @ikalin1 hesabından "Filistin" ve "Kudüs" kelimelerinden en az birini içeren 2 Arapça ve 15 İngilizce Tweet atılırken, Mevlüt Çavuşoğlu'na ait @MevlutCavusoglu hesabından bu kelimelerden en az birini içeren 39 İngilizce ve 3 Arapça Tweet atılmıştır. Cumhurbaşkanı Recep Tayyip Erdoğan’a @RTErdogan hesabından ise “Filistin” ve "Kudüs” kelimelerinden en az birini içeren 3 İngilizce ve 2 Arapça Tweet atıldığı görülmüştür. Türk tarafında ikinci basamakta incelenen diğer hesaplar olan Fuat Oktay’a ait @fuatoktay ve Cumhurbaşkanlığı kurumsal hesabı @tcbestepe hesaplarından “Filistin” ve "Kudüs" kelimelerinden en az birini içeren Arapça veya İngilizce tweetlere rastlanmamıştır. 
kullanıcılar olduğunu söylemek yanlış olmayacaktır. Benzer bir görüşü dile getiren Seib de Trump’n Twitter diplomasisini eleştirirken "sorun Twitter'da değil kullanıcılarda" ${ }^{11}$ ifadesi ile suçlu aranacaksa önce kullanıcılara bakılması gerektiğini ifade etmiştir. Twitter'ın Washington-Ankara hattında bir sorun kaynağı haline gelmesinde Başkan Trump'ın kişisel rolü dikkate alındığında bu ifadenin haklılık payı daha iyi anlaşılacaktır.

Bulgular, her iki tarafın Twitter'ı genel duyuru ve bilgilendirme mesajları dışında kriz dönemlerindeki tepkilerini karşı tarafa iletmek amacıyla kullandıklarını göstermektedir. Fakat "duyurular" dışında kalan ve doğrudan karşı tarafı hedef alan tweetlerin, muhatap alınan yönetim veya kamuoyunu kazanmak ve gerilimi düşürmek bir yana, mevcut anlaşmazlığı daha da keskinleştirmek dışında bir işe yaradığını iddia etmek zordur. Örnek vermek gerekirse, Trump'ın ABD tarafında en önemli konu olarak göze çarpan Brunson Davası sırasında attığı Türkiye'yi hedef alan tweetleri Ankara'daki muhataplarının, ${ }^{52}$ ulusal basının ${ }^{53}$ ve kamuoyunun ${ }^{54}$ büyük tepkisini çekmiş, ilişkilerdeki yerleşik kriz durumu bu tweetler neticesinde daha da belirgin hale gelmiştir. Türk tarafının da Trump'ın tweetlerine yine Twitter ve basın aracıllğıyla sert cevaplar vermesi, ilişkilerde tansiyonun yükselmesi ile sonuçlanmıştır.

Brunson krizine benzer bir başka kriz, Başkan Trump tarafından 14 Ocak 2019'da atılan ve ABD'nin Suriye'den çekilme kararını duyurduğu tweet sonrasında yaşanmıştır. Başkanın bu tweetinde “Türkiye Kürtleri vurursa onları ekonomik olarak mahvederiz” ifadesini kullanması AnkaraWashington arasındaki gerilimi zirveye taşımış ve sorunun çözümüne hiçbir katkı sağlamamıştır. İki ülke arasında varılan mutabakat gereği, 8 Eylül 2019 itibariyle Fırat' in doğusunda ilk ortak kara devriye görevinin icra edilmesi bile tansiyonu düşürememiş, Cumhurbaşkanı Erdoğan $\mathrm{ABD}$ yönetimini Suriye'de Türkiye için değil YPG için güvenli bölge oluşturmaya çalışmakla suçlamıştır. ${ }^{55}$ Türkiye'nin Suriye'deki PYD-YPG faaliyetlerini sonlandırmak ve güvenli bölge oluşturmak için başlatmış olduğu

51 Philip Seib," Donald Trump: Twitter Master”, Huffington Post, 29 Kasım 2017, https://www.huffpost.com/entry/ donald-trump-twitter-master_b_5alf5497e4b0dff40be0363c, (Erişim Tarihi 7 Eylül 2019).

52 “İbrahim Kalın'dan Brunson açıklaması: ABD'nin devam eden bir yargı süreci hakkında keyfi yorum ve taleplerde bulunması dikkate değer bir durumdur. Karar mercii yargıdır ve ABD dahil herkes Türk yargısının vereceği karara saygı duymak zorundadır. Şu ana kadar olduğu gibi bu kural bundan sonra da geçerlidir”, Sözcü, 23 Ağustos 2018, https:// www.sozcu.com.tr/2018/dunya/son-dakika-ibrahim-kalindan-brunson-aciklamasi-2588540/ (Erişim Tarihi 6 Eylül 2019); “Dışş̧leri Bakanı Çavuşoğlu’ndan, Trump’a yanıt: Kimse Türkiye'ye dayatmada bulunamaz”, Hürriyet, 26 Temmuz 2018, http://www.hurriyet.com.tr/disisleri-bakani-cavusoglundan-trumpa-yanit-40909658 (Erişim Tarihi 6 Eylül 2019).

53 “Trump’tan gece yarısı küstah tehdit! Skandal bir tweet daha...”, Milliyet, 17 Ağustos 2018, http://www.milliyet. com.tr/dunya/trump-tan-gece-yarisi-kustah-tehdit-skandal-bir-tweet-daha-2726469 (Erişim Tarihi 6 Eylül 2019); “ABD Başkanı Donald Trump'tan küstah Brunson tehdidi!”, Takvim, 28 Temmuz 2018, https://www.takvim.com.tr/ guncel/2018/07/26/abd-baskani-donald-trumptan-kustah-brunson-tehdidi (Erişim Tarihi 6 Eylül 2019); "Trump yine Türkiye'ye saldırdı”, Sabah, 17 Ağustos 2018, https://www.sabah.com.tr/dunya/2018/08/17/trump-yineturkiyeye-saldirdi (Erişim tarihi 6 Eylül 2019); “Trump'tan Türkiye’ye Rahip Brunson Tehdidi”, Hürriyet, 26 Temmuz 2018, http://www.hurriyet.com.tr/dunya/abd-baskani-donald-trumptan-turkiyeye-rahip-brunson-cagrisi-40909596 (Erişim Tarihi 6 Eylül 2019).

54 Türkiye Sosyal ve Siyasal Eğilimler Araştırması 2018 sonuçlarına göre, Türk kamuoyunun yüzde 81,9'u ABD’ni Türkiye için bir tehdit olarak algılamaktadır. Bu oranın 2016 yılı için yüzde 60,4 olduğu düşünülürse ABD ile yaşanan krizlerin Türk kamuoyunda yarattığı tepkinin boyutu daha net anlaşılacaktır. Araştırma sonuçları için bkz. Mustafa Aydın et. all., Türkiye Sosyal ve Siyasal Eğilimler Araştırması 2018, İstanbul, Kadir Has Üniversitesi Türkiye Araştırmaları Merkezi, 30 Ocak 2019.https://www.khas.edu.tr/uploads/turkiye-sosyal-siyasal-egilimler-arastirmasi-2018.pdf , (Erişim Tarihi 13 Aralik 2019)

55 "Erdoğan: Güvenli bölge için ABD ile görüşüyoruz ancak istediklerimizle onların kafalarındakinin aynı şey olmadığını attığımız her adımda görüyoruz”, BBC Türkçe, 8 Eylül 2019, https://www.bbc.com/turkce/haberler-turkiye-49625563 (Erişim Tarihi 9 Eylül 2019). 
Barış Pınarı operasyonu öncesinde ve sonrasında (7-19 Ekim 2019) yine ABD Başkanı Trump tarafından atılan tweetlerin iki ülke arasındaki gerilimi tırmandırmaktan başka bir işe yaramadığını söylemek yanlış olmayacaktır.

Taraflar Twitter’ kriz dönemi gündemleri için bir araç olarak kullanarak kendi seçmenlerinin gözünde konumlarını sağlamlaştırmış olabilirler ve bu iç politikada bir başarı öyküsü olarak görülebilir. İçeride ve dışarıda belirlenmiş bir hedef kitleye ulaşmanın ve o kitleyi kazanmanın getirisi, dış politikada her an yaşanabilecek günlük krizlerin maliyetlerinin görmezden gelinmesini sağlayacak kadar cazip de olabilir. Fakat dış politikanın siyasetçiler tarafından popülizme malzeme edildiği bu tarz söylem ve eylemlerin ikili ilişkilerdeki sorunların çözülmesini güçleştirdiği de dikkate alınmalıdır. Twitter üzerinden yürütülen kamuoyu kazanma kampanyaları halklar arası düşmanlığı körüklemekte ve bu keskin bakış açısı yine halk tarafından iktidara bir baskı olarak yansıtılarak bumerang etkisi yaratmaktadır. Bilhassa Türkiye tarafında son yıllarda düzenli olarak yapılan kamuoyu yoklamalarında Türk halkının en büyük tehdit olarak ABD'yi görmesi ${ }^{56}$ ve bu algının da karar alıcılar üzerinde sorunların çözümünü zorlaştırıcı baskı oluşturması şaşırtıcı değildir. Her iki taraftaki tehdit algısı keskinleştikçe, sorunların "teknik meseleler” olmaktan çıkması ve varoluş sorunu olarak ele alınması kaçınılmaz olacaktır.

Her iki taraftaki karar alıcıların genelde sosyal medyaya, özelde ise Twitter'a bakışları bu platformun ikili ilişkilerin yakın geleceğinde oynayabileceği rol hakkında ipuçları barındırmaktadır. Bir mülakat sırasında sosyal medyayı neden bu kadar çok kullandığının sorulması üzerine "Twitter olmasaydı burada olamazdım" ${ }^{\not 7}$ cevabını veren Trump, başkan seçilmesinde bu kadar etkin bir rol oynayan Twitter'ı hem iç hem de dış politika aracı olarak kullanmaktan vazgeçmemiştir. Trump'ın Twitter diplomasisi, ekibini ve dışişleri bakanlığını da bu dönüşüme uyum sağlamaya zorlamıştır. Başkanın ekibinden olan ve yine başkan tarafından atılan bir tweetle kovulduğu duyurulan eski Dışişleri Bakanı Rex Tillerson, görevdeyken başkanın tweetlerinin çıktısının alınarak kendisine getirildiğini ve ilk başta geleneksel olmadığı için bu yeni yönteme alışmakta zorlandığını söylerken, aslında klasik yöntemlere alışık dışişleri teşkilatının da Trump'ın Twitter diplomasisine uyum sağlamakta güçlük çektiğini itiraf etmiştir. ${ }^{58}$ Öte yandan, ulusal güvenlik danışmanı John Bolton, Venezuela'daki politik kriz süresince konu ile ilgili 150 'den fazla tweet atarak ${ }^{59}$ Başkanın Twitter diplomasisine uyum dönemini çabuk atlatmış gözükse de, bu çabası bile Eylül 2019'da görevden alınmasını engelleyememiştir. Trump'ın skandallarla dolu Twitter diplomasisi sicili ${ }^{60}$ ve ekibinin

56 Mustafa Aydın, et.all., tarafından son yıllarda düzenli olarak yapılan Türk Dış Politikası Kamuoyu Algıları Araştırması sonuçlarına ulaşmak için bkz. http://ctrs.khas.edu.tr/26/turk-dis-politikasi-algilari-anketi (Erişim Tarihi 22 Ekim 2019).

57 Lionel Barber et al., "Donald Trump: Without Twitter, I would not be here”, Financial Times, 2 Nisan 2017, https:// www.ft.com/content/943e322a-178a-11e7-9c35-0dd2cb31823a, (Erişim Tarihi 20 Ağustos 2019)

58 Sophie Tatum, “Tillerson's staff prints out the President's tweets for him to read”, CNN, 28 Ocak 2018, https://edition. cnn.com/2018/01/17/politics/tillerson-donald-trump-twitter/index.html, (Erişim Tarihi 8 Eylül 2019).

59 Mark Landler, Katie Rogers, “Trump’s Aides Are Imitating His Aggressive Twitter Diplomacy. The Results Are Mixed.”, The New York Times, 7 Mart 2019, https://www.nytimes.com/2019/03/07/us/politics/trump-administration-twitterdiplomacy.html, (Erişim Tarihi 7 Eylül 2019).

60 Trump'in Kuzey Kore Devlet Başkanı Kim Jong-un’a Twitter üzerinden "akıl hastası”, "kısa ve şişman”, "roket adam” ve "hasta köpekçik” sözleriyle hitap etmesi ve Kim’in de hakaret dolu mesajlarla karşıllk vermesi ilişkilerin gerilmesine sebep olmuştur. Zehra Yıldız, “'Hasta köpekçik', 'Akıl hastas1, 'Roket adam’: Trump ve Kim’in hakaret arşivi”, Euronews, 11 Haziran 2018, https://tr.euronews.com/2018/06/11/-hasta-kopekcik-akil-hastasi-roket-adam-trump-ve-kimin-hakaret-arsivi (Erişim Tarihi 7 Eylül 2019). Trump’ın başkanlığının ilk yılında attığı tweetlerle sebep olduğu tüm diplomatik krizler için bkz. Krishnadev Calamur, “The International Incidents Sparked by Trump’s Twitter Feed in 
Twitter diplomasisine gönüllü veya zoraki uyumu, bugüne kadar Ankara-Washington hattındaki gerilimi azaltamayan ve daha da büyüten bu dijital diplomasi aracının yakın gelecekte de ilişkilerin gündeminde kalacağı ihtimalini kuvvetlendirmektedir.

Türkiye tarafında incelenen aktörlerin ise ikili ilişkileri yürütmede her ne kadar aktif olarak kullansalar da Twitter'ın gündelik yaşamdaki ve politikadaki rolü üzerine daha şüpheci bir tutum sergilediklerini söylemek yanlış olmayacaktır. Örneğin, Cumhurbaşkanı Tayyip Erdoğan’ın Başkan Trump'in aksine Twitter'a dair son derece olumsuz düşüncelere sahip olduğu bilinmektedir:

"Şu anda Twitter denilen bir bela var, yalanın daniskası burada. Sosyal medya denilen şey aslında şu anda toplumların baş belasıdır". "B1 "Biliyorsunuz ben bu sosyal medyaya karşıyım. Bundan dolayı bana çok saldırı da oldu. Ben bu Twitter’a filan hepsine karşıyım ve bunları paylaşmıyorum. Kendim de kullanmıyorum. Benim adıma kullananlar var, o ayrı mesele." ${ }^{62}$

Türkiye tarafında tıpkı Erdoğan gibi Twitter’ın politika ve özellikle dış politika yürütümündeki rolüne şüpheyle bakanlardan biri de Dışişleri Bakanı Çavuşoğlu'dur. Trump'ın Twitter üzerinden savurduğu tehditleri değerlendirirken "stratejik ortaklar sosyal medya üzerinden konuşmaz" ifadesini kullanan Çavuşoğlu, Başkan'ın Twitter mesajlarının ilişkilerdeki olumsuz etkilerine dikkat çekmiştir. ${ }^{63} \mathrm{Bu}$ çalışmada incelenen hesaplardan atılan tweetlerin ağılıklı olarak toplantı ve görüşme duyurularından oluşması da Türk tarafının Twitter diplomasisine ikili ilişkiler bağlamında sıcak bakmadığının göstergesidir. Ancak hem Erdoğan'ın hem de Çavuşoğlu'nun, kendi danışmanları aracılığ 1 ile Twitter başta olmak üzere belli başlı sosyal medya platformlarında sürekli görünür olmaları, bu yeni dijital aracın sadece diplomasiyi değil, tüm politika alanlarını ve aktörlerini nasıl bir değişime zorladığının işaretidir.

Her iki ülkenin dışişleri teşkilatları iletişim devrimiyle değişime zorlanan yeni diplomasiye ve özellikle Twitter diplomasisine hazır mıdır? Bu konuda ilk adımları atan ve sosyal medya görünürlüğü üzerine çalışan çeşitli birimler oluşturan ABD Dışişleri Bakanlığı’nın Twitter'ın kamu diplomasisi boyutuna büyük önem verdiğini söylemek yanlış olmayacaktır. Bakanlık bünyesinde faaliyet gösteren Küresel Sosyal Medya Bürosu (KSMB), bakanlığın Twitter, Facebook, Flickr, Youtube ve Instagram hesaplarını idare etmektedir. Misyonunu "yeni medya ve web tabanlı iletişim teknolojileri aracılığı ile Amerikan dış politikasının menzilini genişletmek” olarak tanımlayan KSMB, Dışişleri Bakanlı̆̆’nın Twitter'daki Arapça, Rusça, Farsça, İspanyolca, Portekizce ve Urdu dillerindeki hesaplarından da sorumludur. Fakat dijitalleşme ve dijital platformlarda görünürlüğe hızla uyum sağladığı görülen ve

2017: From minor disputes with Sweden to major ones with North Korea”, The Atlantic, 19 Aralık 2017, https://www. theatlantic.com/international/archive/2017/12/trump-tweets-foreign-policy/547892/ (Erişim Tarihi 7 Eylül 2019). Trump'in son olarak İngiltere'nin Washington Büyükelçisi Kim Darroch için Twitter üzerinden “İngiltere'nin ABD’ye kakaladığı kaçık büyükelçi bizi heyecanlandıran biri değil, çok aptal bir adam. Elçi, önce başarısız Brexit müzakereleri hakkında kendi ülkesi ve Başbakan May ile konuşmalı” ifadelerini kullanması, İngiltere ve ABD arasında krize neden olmuş ve skandallarla dolu Twitter diplomasisi siciline yeni bir kayıt olarak geçmiştir. Hakan Çopur, Hasan Esen, “Trump İngiltere'nin ABD Büyükelçisine 'aptal' dedi”, Anadolu Ajansı, 9 Temmuz 2019, https://www.aa.com.tr/tr/ dunya/trump-ingilterenin-abd-buyukelcisine-aptal-dedi/1527266 (Erişim Tarihi 7 Eylül 2019).

61 “Erdoğan: Twitter denen bir bela var", NTV, 2 Haziran 2013, https://www.ntv.com.tr/turkiye/erdogan-twitter-denilenbir-bela-var,nNAKG2OAMUewglwLKFVNfA (Erişim Tarihi 9 Eylül 2019).

62 “Cumhurbaşkanı Erdoğan: Ben bu Twitter’a falan hepsine karşıуım”, CNN Türk, 2 Temmuz 2016, https://www.cnnturk. com/turkiye/cumhurbaskani-erdogan-ataturk-havalimaninda, (Erişim Tarihi 9 Eylül 2019).

63 “Çavuşoğlu: Stratejik Ortaklar Sosyal Medya Üzerinden Konuşmaz", Anadolu Ajansı, 14 Ocak 2019, https://www.aa.com. $\mathrm{tr} / \mathrm{tr} /$ gunun-basliklari/disisleri-bakani-cavusoglu-stratejik-ortaklar-sosyal-medya-uzerinden-konusmaz/1364092 (Erişim Tarihi 9 Eylül 2019). 
kamu diplomasisi yürütürken bu araçları sıkça kullanan ABD Dışişleri Bakanlığı, klasik diplomasi araçları ile kıyaslandığında Twitter’’ ikili ilişkileri yürütürken öncelikli bir araç olarak görmemektedir. Başkan'ın Twitter diplomasisi, ABD’nin sanal dünyadaki görünürlüğ̈nü arttırsa da bütçe kısıntıları ve tecrübeli diplomatların istifaları ile kan kaybı yaşayan dışişleri teşkilatını politika oluşturma ve yürütme sürecinden daha da dışlamıştır. ${ }^{64}$ Calamur'un The Atlantic için kaleme aldığı çalışmasında ismini vermek istemeyen iki ABD Dışişleri Bakanlığı çalışanı, bilhassa Başkanın ikili ilişkileri yürütürken Twitter kullanmasını tasvip etmediklerini ve yine Başkan tarafından atılan tweetlerin teşkilatın hem moralini bozduğunu hem de tüm diplomatları çok zor durumda bıraktığını ifade etmektedirler. ${ }^{65}$

Türkiye Cumhuriyeti Dışişleri Bakanlığı da Türk tarafında dijital diplomasiye en çabuk uyum sağlayan teşkilat olarak ön plana çıkmaktadır. Yurtdışında yaşayan yaklaşık 6 milyon vatandaşın konsolosluk hizmetlerini kesintisiz almasını sağlayan e-konsolosluk servisinin yanı sıra, e-vize ve e-nota gibi servislerle dikkat çeken Dışişleri Bakanlığ Youtube, Facebook ve Twitter aracılığ 1 ile sosyal medyada yer almaktadır. Twitter’a @TC_Disisleri kullanıcı adıyla Aralık 2009'da katılan bakanlık, bu hesabı güncel konulardaki basın açıklamaları ve diplomatik temaslar hakkında bilgi vermek amacıyla aktif olarak kullanmaktadır. Öte yandan, Ankara'daki bakanlık merkez teşkilatı dışında Türkiye’nin yurtdışındaki diplomatik temsilciliklerinin ve konsolos-büyükelçi düzeyindeki diplomatlarının da vatandaşları bilgilendirmek amacıyla çeşitli sosyal medya platformlarını kullandıkları bilinmektedir. Fakat bakanlığın sosyal medyadaki tüm bu görünürlüğüne rağmen, ikili ilişkileri Twitter üzerinden yürütmeye sıcak bakmadığını tahmin etmek güç değildir. Dışişleri Bakanlığı́nın üst düzey bürokratlarının, tıpkı ABD’deki meslektaşları gibi, giderek yaygınlaşan sosyal medya kullanımına uyum sağlamaları kaçınılmazdır. Ancak etkileri hesaplanmadan gönderilen ve krizleri kamuoyu önüne taşıyan Twitter mesajlarının, en azından diplomatlar nezdinde, klasik araçların yanında dikkatle kullanılması gereken ikincil bir araç olarak kalması beklenmelidir.

\section{Sonuç}

Çalışmadaki bulgular, ilk olarak Twitter diplomasisinin ikili ilişkiler çerçevesinde özellikle ABDBaşkanı Trump tarafından sıkça kullanıldığını, Türk tarafındaki aktörlerin ise klasik diplomasi araçlarını daha çok tercih ettiklerini göstermektedir. İkinci önemli bulgu, Türk tarafındaki konu çeşitliliğinin tersine Amerikan tarafındaki konu kısıtlılı̆gı olmuştur. Üçüncü önemli bulgu ise tarafların Twitter'ı sadece dış politika icrası için değil, dış politika konularını iç politika malzemesi yapmak amacıyla da kullandığının görülmesidir. Bu bulgular ışığında Twitter diplomasisinin Türk-Amerikan ilişkilerinde her an veya mevcut krizleri büyütebilecek bir araca dönüştügünü söylemek yanlış olmayacaktır. Bir başka deyişle, bu çalışma Türk-Amerikan ilişkileri özelinde Twitter diplomasisinin kriz çözücü değil, kriz tırmandırıcı etkilerinin daha belirgin olduğu sonucuna varmıştır.

Franklin D. Roosevelt'in 1939 yılında ilk kez televizyon yayını aracılı̆̆ı ile yurttaşlara ulaşmasından günümüze uzanan süreçte, tüm $\mathrm{ABD}$ başkanları kitle iletişim araçlarını giderek artan biçimde kullanır hale gelmişlerdir. Bu kullanımın dış politika boyutuna bakıldığında hem

64 Grona Grigic, “Twelve Months of Trump: Making Sense of the Donald Doctrine”, Australian Outlook, 13 Ocak 2018, http://www.internationalaffairs.org.au/australianoutlook/first-year-donald-doctrine/ (Erişim Tarihi 13 Eylül 2019).

65 Krishnadev Calamur, “Are Trump's Tweets Undercutting U.S. Diplomacy?”, The Atlantic, 3 Ekim 2017, https://www. theatlantic.com/international/archive/2017/10/trump-tillerson/541671/ (Erişim Tarihi 9 Eylül 2019). 
kullanıcılara yönelik bir kamu diplomasisi faaliyetinin hem de ikili ilişkilerdeki muhataplara doğrudan mesaj iletmenin amaçlandığı görülmektedir. Başkanlar ve dışişleri bakanları aracılı̆̆ ile Küba Füze Krizi’nden İran'la yaşanan Rehine Krizi’ne, Körfez Savaşı'ndan Irak'ın İşgali' ne kadar pek çok konu ABD kamuoyu ile paylaşılmış ve krizin diğer tarafındaki muhataplara en yetkili ağızlardan mesajlar da bu yolla iletilmiştir. Türkiye tarafında da önce radyo, 1968 sonrasında ise televizyon yayınları karar alıcıların sıkça başvurduğu kitle iletişim araçları olmuştur. Dış politika da bu kitle iletişim araçlarının sıkça kullanıldığı bir alan olmuştur. Çeşitli hükümetler, Kıbrıs Barış Harekâtından Kardak Krizi’ne kadar pek çok mesele üzerine görüş, beklenti ve tepkilerini televizyon yayınları aracıllğı ile halka ve krizin karşı taraftaki muhataplarına duyurmuşlardır.

Karar alıcılar ve diplomatların dış politika yürütürken başvurdukları araçların arasına son yıllarda eklenen ve giderek daha fazla ilgi çekmeye başlayan Twitter, klasik diplomasinin maruz kaldığı değişim ve dönüşümün en görünen ve en çok bilinen yüzü haline gelmiştir. Twitter diplomasisi, deneyimli diplomatların denetlemelerinden geçmiş ve büyük bir titizlikle hazırlanan basın açıklamaları, duyurular ve diplomatik yazışmaların yerini alamasa da, yardımcı bir dış politika yürütme aracı olarak kendine kısa zamanda önemli bir yer edinmiştir. Yakın gelecekte de sadece Twitter'ın değil, tüm sosyal medya platformlarının hem kamu diplomasisi çerçevesinde kitlelere ulaşmak hem de ikili ilişkileri yürütmede mesaj iletmek için önemli araçlar olmaya devam edecekleri öngörülmektedir. Ancak Twitter diplomasisinin dış politika yürütülmesi kapsamında olumlu bir katkı sağlaması için hem karar alıcıların hem de dış politika yürütücülerinin bu sanal platformun bilinçli kullanımı konusunda son derece dikkatli olmaları gerekmektedir.

İkili ilişkiler bağlamında Twitter diplomasisi ile ilişkilendirilen krizlerin kullanıcılardan kaynaklandığı göz önüne alındığında hem politikacılar hem de dışişleri bakanlığı bürokratları için bir "yapılması gerekenler" ve/veya "kaçınılması gerekenler” listesi oluşturmak zaruri hale gelmiştir. Karar alıcıların dış politika meselelerinde doğrudan muhataplarını hedef alan paylaşımlar yapmadan önce ilgili danışmanların kontrolüne ve onayına başvurmaları; lider danışmanlarının ve dışşşleri bakanlığı bürokratlarının rutin sosyal medya kullanımı eğitimlerine katılmaları; ikili ilişkileri yürütürken sosyal medya kullanımının diplomasinin klasik araçlarına kıyasla yardımcı bir unsur olarak görülmesinin ve kullanılmasının içselleştirilerek bir kural haline getirilmesi, hiç kuşku yok ki “yapılması gerekenler” listesinin başlarında yer almalıdır. Bakanlıklar ve müsteşarlıklar gibi farklı kurumlar tarafından teyit edilmemiş bilgilerin sosyal medyada sunulması, gizli kalması gereken bilgilerin ve görsellerin gerekli izinler alınmadan paylaşılması, sosyal medyanın anlık kişisel tepkilerin iletilmesi amacıyla kullanılması ve sosyal medya üzerinden yine kişisel tartışmalara girilmesi gibi davranışlar da "yapılmaması gerekenler” arasında sayılabilir. Diplomaside sosyal medyanın gücünün giderek arttığı çağımızda, bu gücün zarar verici olmaktan çıkıp yararlı hale dönüşmesi için ideali veya olması gerekeni sıralayan bu listenin göz ardı edilmemesi büyük önem taşımaktadır. Aksi takdirde ülkeler arasında yeni ve beklenmedik krizlerin patlak vermesi, mevcut krizlerin ise daha da derinleşmesi olasılık dahilinde olacaktır.

Özelde Twitter'ın genelde ise sosyal medyanın, politikanın her alanında giderek artış gösteren gücü bugün kesinlikle yadsınamaz hale gelmiştir. Sosyal medyanın gücüne dair farkındalığın oluşması, tüm politikacıların sosyal medya platformlarındaki görünürlüklerinin artması ile sonuçlanmıştır. Gönder bağlantısına tıklayarak milyonlarca kullanıcıya zaman-mekân sınırlaması olmaksızın saniyeler içinde ulaşmak, karar alıcıları hem kendi kişisel politik amaçlarını gerçekleştirmek hem de temsil 
ettikleri devletlerin çıkarlarını savunmak için sosyal medyayı daha yoğun kullanmaya itmektedir. Bu kadar etkili bir aracın bilhassa dış politika yürütürken titizlikle kullanılması ve kontrol/otokontrol filtrelerinden bağımsız olmaması önemlidir. Sonuçları düşünülmeden atılacak mesajların doğrudan veya dolaylı biçimde uluslararası para piyasalarında dalgalanmalar yaratması, iç karışıklıklara neden olması, yabancı ülke temsilcilerini hedef haline getirmesi, belirli bir millet veya inanca mensup kişilere yönelik nefret suçlarına sebep olması ve hatta silahlı çatışma olasılığını arttırması mümkündür. Öte yandan, Twitter başta olmak üzere sosyal medyanın dış politika yürütümünde doğru kullanılması, yine doğrudan veya dolaylı olarak ülkenin tanınırlığını arttıracak, o ülkeye dair varsa önyargıların ortadan kalkmasına hizmet edecek ve ülkenin politik ve ekonomik istikrarına katkıda bulunacaktır. Görünen o ki Twitter başta olmak üzere tüm sosyal medya platformları, sahip oldukları gücün cazibesi nedeniyle yakın gelecekte de politika alanlarının ve diplomasinin önemli bir parçası olmaya devam edeceklerdir. Fakat dış politikadaki giderek artan sosyal medya kullanımının sonuçlarının olumlu mu yoksa olumsuz mu olacağı, karar alıcıların iradeleri ve sorumluluk bilinçlerine göre şekillenecektir. 